\title{
Altered basement rocks on the Utsira High and its surroundings, Norwegian North Sea
}

\author{
Lars Riber ${ }^{1}$, Henning Dypvik' \& Ronald Sørlie² \\ ${ }^{1}$ Department of Geosciences, University of Oslo, P.O. Box 1047, Blindern, 0316 Oslo, Norway. \\ ${ }^{2}$ Lundin Norway AS, Strandveien 50D, 1366 Lysaker, Norway. \\ E-mail corresponding author (Lars Riber): lars.riber@geo.uio.no
}

\begin{abstract}
As part of the recent discoveries on the Utsira High (Edvard Grieg and Johan Sverdrup fields), altered and fractured basement rocks were for the first time shown to act as a reservoir and possible migration paths for commercial hydrocarbon deposits on the Norwegian Continental Shelf.Altered basement rocks are underlying the main Upper Jurassic reservoir rocks in Johan Sverdrup and the main Cretaceous, Jurassic and Triassic reservoir rocks in Edvard Grieg. In the present study, eighteen basement cores from the Utsira High have been classified and investigated for signs of alteration, including subaerial weathering. The results show highly variable basement composition, including metasandstones, phyllites, granites, granodiorites and gabbroic rocks. In core view most of the basement rocks show signs of a medium to high degree of fracturing. Alteration has taken place in most of the cores, ranging from slight discoloration to disintegration along fractures, and to total fragmentation of the rock. The fragmentation of the rock is commonly associated with the dissolution of primary minerals and precipitation of secondary clays in the newly formed pore space. The upwards increasing disintegration and increasing amount of clay observed in the basement rocks from two of the wells (16/3-4 and 16/1-15) indicate that subaerial weathering was the main alteration agent.
\end{abstract}

Keywords: Utsira High, North Sea, weathered basement, fractured basement, petroleum

Electronic Supplement: Electronic Supplement 1-17

Received 3. November 2014 / Accepted 22. May 2015 / Published online 20. August 2015

\section{Introduction}

The Norwegian North Sea is a mature hydrocarbon province which has been mapped extensively since the discovery of oil and gas in the late 1960s. However, in recent years, a new play concept has revitalised oil and gas exploration on the Norwegian Continental Shelf (NCS), and areas which were earlier overlooked are now the subject of renewed interest to industry.

In conventional exploration, crystalline and metamorphic basement is usually regarded as the lower limit of the oil-bearing formations, and most oil companies stop drilling operations as soon as basement is reached. Thus, most of the earlier basement discoveries were found largely by accident (Landes et al., 1960).
It was not until around 1990 that companies started to specifically target basement rocks when searching for hydrocarbons and in recent years several large discoveries have been made (Farag et al., 2009; Gutmanis, 2009). Onshore Norway, most of previously existing Mesozoic and Cenozoic sediments have been removed by Cenozoic erosion following several episodes of uplift (see Lidmar-Bergström et al., 1999 for full list of references). However, isolated pockets of deeply weathered rocks have been preserved at several localities (Roaldset et al., 1982; Sørensen, 1988; Olesen et al., 2006, 2013). These remnants have been attributed to chemical weathering processes during a subtropical climate in TriassicJurassic time (Lidmar-Bergström, 1982). Researchers have known for decades about the presence of fractured and weathered crystalline rocks offshore in the

Riber, L., Dypvik, H. \& Sørlie, R. 2015: Altered basement rocks on the Utsira High and its surroundings, Norwegian North Sea. Norwegian Journal of Geology 95, 57-89. http://dx.doi.org/10.17850/njg95-1-04.

(c) Copyright the authors.

This work is licensed under a Creative Commons Attribution 4.0 International License. 


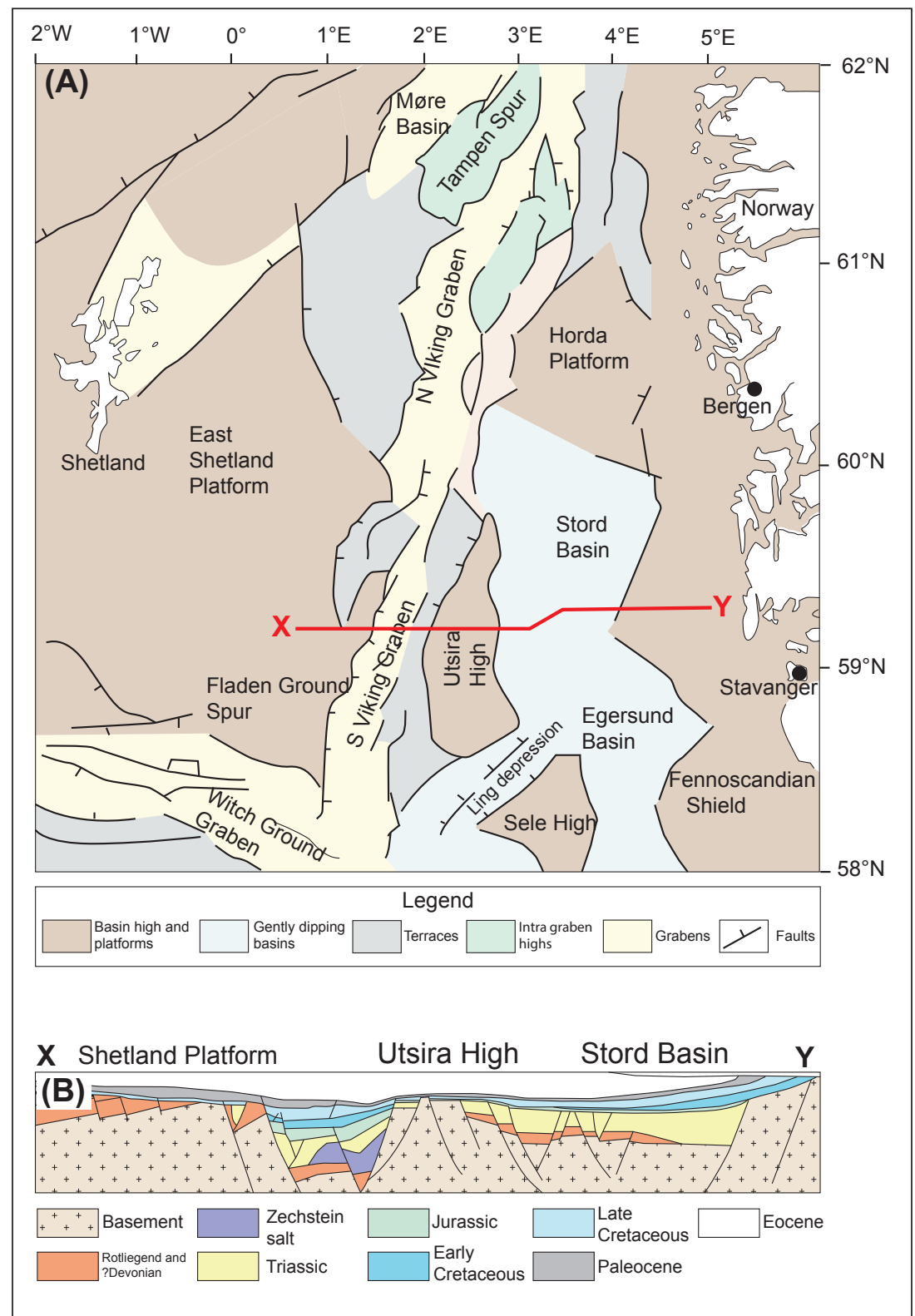

Figure 1. (A) Regional map of the North Sea area (modified from Gregersen, 1997) with cross-section marked X-Y. (B) Cross-section (X-Y) of the South Viking Graben (modified from Ziegler, 1992).

Norwegian sector. Earlier studies of core samples have suggested the weathering to be of Jurassic or pre-Jurassic age, probably time equivalent to the onshore remnants (Roaldset et al., 1993).

The Utsira High is an intrabasinal structural high located $190 \mathrm{~km}$ west of Stavanger, in the Norwegian North Sea (Fig. 1). The first discovery of oil in Norway was made by ESSO in 1967, in well 25/11-1 on the northwestern flank of the Utsira High, in what is now called the Balder Field (Fig. 2). Since then the central and northern parts have been actively explored and encompass several oil and gas fields including Balder, Heimdal, Jotun, Ringhorne and Grane (Fig. 2B). Early exploration on the southern part of the high revealed minor oil and gas shows but was deemed not commercially exploitable. Interestingly, hydrocarbons were also reported in well reports from fractured and brecciated basement rocks (e.g., 16/1-4) (www.npd.no) (Fig. 2).

In 2004, Lundin Norway AS acquired the 338 license in the southern part of the Utsira High, and in 2007 the first well, 16/1-8, was drilled in the Luno Prospect (later to be the Edvard Grieg Field) (Fig. 2). The well encountered an oil column of about $40 \mathrm{~m}$ in Norian (Upper Triassic) sandstones and feldspar-rich conglomerates. Following this discovery, several successful wells have been drilled in the Edvard Grieg Field. South of the discovery well, in well 16/1-12, oil was detected in altered/fractured granitic basement (www.npd.no) (Fig. 2). In well 16/1-15, in the northern part of the Edvard Grieg Field (the Tellus prospect), good reservoir conditions were discovered in altered and fractured crystalline rocks (www.npd.no) (Fig. 2). 
In the Statoil-operated Ragnarock prospect, just east of the Edvard Grieg Field, the main reservoir has been discovered in Upper Cretaceous chalks, but minor amounts of oil have also been observed in fractured basement cores (www.npd.no) (Fig. 2).

In 2010, Lundin Norway drilled the Avaldsnes discovery (later to be the Johan Sverdrup Field) in licence 501, around $25 \mathrm{~km}$ east of the Edvard Grieg Field (Fig. 2). Well 16/2-6 was a success, with the main reservoir present in the sands of the Upper Jurassic Draupne Formation (Fig. 3). Subsequent appraisal wells in licence 501, and in the Statoil-operated Aldous Major (now part of the Johan Sverdrup Field) in licence 265 and licence 502 , have confirmed one of the largest oil discoveries on the NCS (Fig. 2) (Sørlie et al., 2014; www.npd.no). Although the main reservoir is found in Upper Jurassic rocks, the altered and fractured crystalline basement has an important role in the play concept. Porous and permeable basement rocks may have good reservoir properties

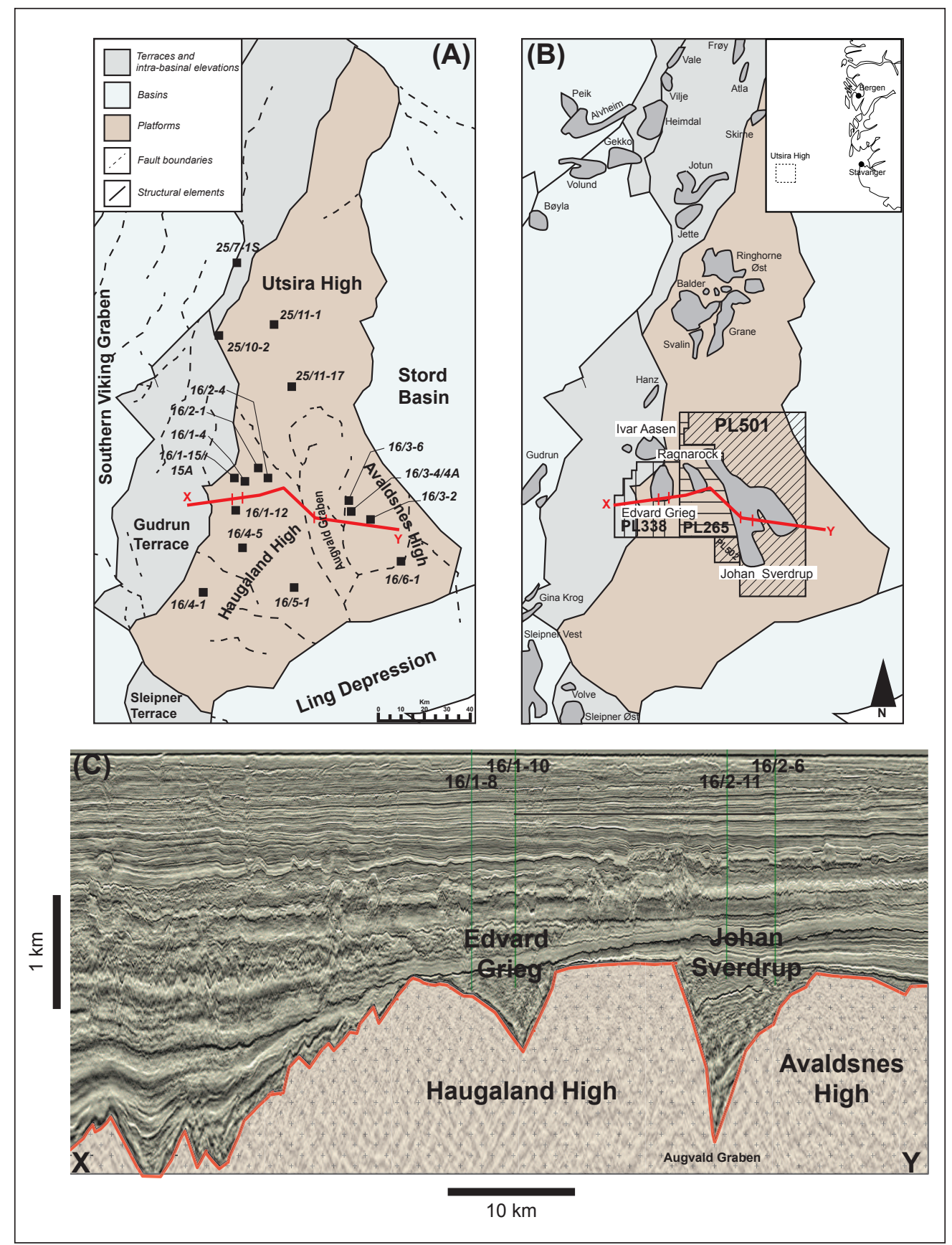

Figure 2. Map of the Utsira High. (A) Major structural elements and wells penetrating basement used in this study. Red line (X-Y) denotes seismic cross-section. Tic marks on the line show projections of well positions displayed on the cross section. (B) The main fields and discoveries, and production licences in the Edvard Grieg and Johan Sverdrup area (ARCGis files from www.npd.no). (C) E-W seismic cross section (X-Y) showing main structural elements on the Haugaland high, Avaldsnes high, and the Edvard Grieg and Johan Sverdrup fields (courtesy of Lundin AS). The positions of four wells is projected on the profile. 


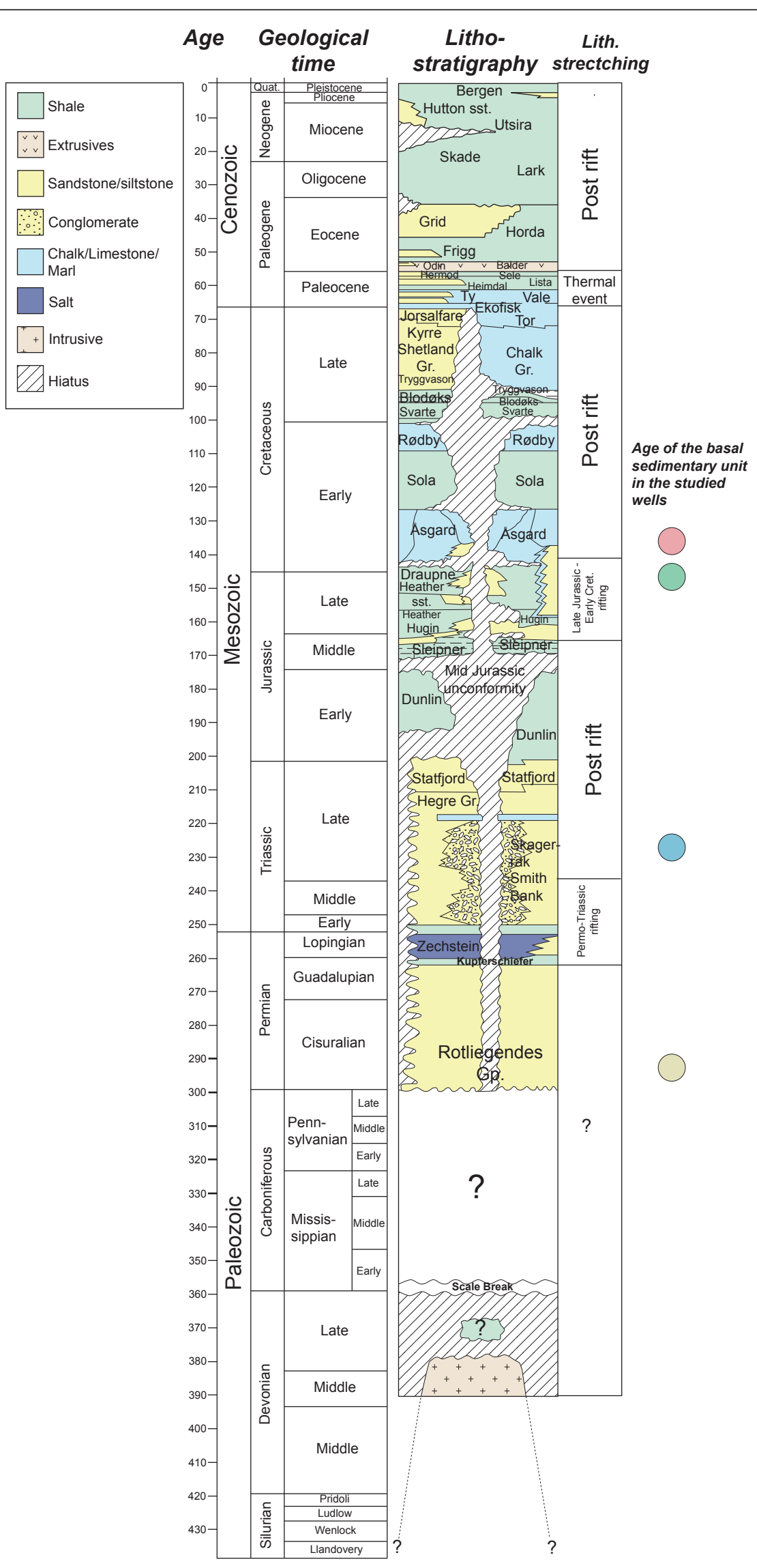

Figure 3. Stratigraphic column from the Southern Viking Graben (modified from the NORLEX Project, 2012). The main rifting phases in the northern North Sea area (Odinsen et al., 2000) and the age of the basal sedimentary units (www.npd.no) from cores included in the study are displayed by circles. Red circle: 16/1-4, 16/1-15, 16/1-15A, 16/2-1, 16/2-4, 16/4-5 and 16/5-1. Green circle: 16/1-12, 16/3-2, 16/3-4, 16/3-4A, 16/3-6 and 16/6-1. Blue circle: 25/11-1. Yellow circle: 16/4-1,25/10-2R and 25/11-17. 
and they can also have served as migration pathways for hydrocarbons. Furthermore, the eroded weathering material was probably deposited in nearby sedimentary basins on the Utsira High (Sørlie et al., 2012)

Following the great success of the southern Utsira High fields, it is likely that the concept of basement rocks as part of a petroleum play will be tested in other areas on the NCS. Because of the many wells penetrating basement rocks and the huge amount of available data, the Utsira High is a suitable area to study the processes and conditions responsible for the alteration and decomposition of crystalline bedrock on the NCS.

The project includes eighteen basement cores from the Utsira High which have been made available by the Norwegian Petroleum Directorate (NPD) and Lundin Norway AS (see Electronic Supplement 1-16). The aim of the present study was to first characterise and classify basement rocks of different composition and origin observed on the Utsira High and its surroundings. Next, the basement cores have been closely investigated for signs of alteration, with focus on subaerial weathering. Signs of alteration include the physical fragmentation of the rocks, the dissolution of primary minerals and precipitation of secondary phases. This paper, which presents the first compilation of altered basement rocks from this part of the Norwegian North Sea, will form the basis for future publications where detailed clay mineralogical and geochemical studies will be carried out (Riber et al., in prep.).

\section{Geological setting}

The flooded North Sea palaeorift system forms a minor epicontinental basin confined by the Shetland Platform to the west and the Norwegian mainland to the east (Fig. 1). The N-S-trending Viking-Central Graben has a length of approximately $1000 \mathrm{~km}$ and a width that varies between 25 and $100 \mathrm{~km}$ (Ziegler, 1992; Nøttvedt et al., 1995).

The North Sea basin is composed of several major Mesozoic grabens and highs (Gregersen et al., 1997). The Utsira High is one of the intrabasinal structural highs forming the eastern flank of the southern Viking Graben. It is delimited to the east and north by the Stord basin and to the south by the Ling depression (Figs. 1, 2). The southern part of the Utsira High is referred to as the Haugaland high (informal name) in Fig. 2, while the Augvald graben (informal name) separates the main Utsira High from the Avaldsnes high (informal name) to the east (Fig. 2).

The North Sea sedimentary basin rests on crust which was involved in the Early Palaeozoic closure of the North Iapetus Ocean, and the subsequent collision and sub- duction of the western margin of the continent Baltica beneath Laurentia in the Late Silurian-Early Devonian (Fig. 4). The collision culminated in the rise of the Caledonian mountain range. To the south, microcontinental terranes (Avalonia) had separated from Gondwanaland in Early Ordovician and were drifting northwards, and thus closing the Southern Iapetus and the Tornquist Sea before colliding with Baltica in Late Ordovician times (Soper et al., 1992; Rey et al., 1997; Pharaoh, 1999; Coward et al., 2003) (Fig. 4).

Frost et al. (1981), Slagstad et al. (2011) and Lundmark et al. (2013) have dated crystalline basement rocks from the Utsira High, with ages spanning from 409 to $482 \mathrm{Ma}$. The older group of rocks ( $>455 \mathrm{Ma}$ ) most likely represent Ordovician intrusions in a volcanic arc setting, where the inherited zircon composition suggests a Laurentian affinity (Slagstad et al., 2011). The younger group of intrusions $(<455 \mathrm{Ma})$ is believed to represent magmatic episodes related to the closure of the Iapetus Ocean and continent-continent collision in the Late Silurian-Early Devonian (Slagstad et al., 2011; Lundmark et al., 2013) (Fig. 4).

By earliest Devonian, the Caledonian mountain chain was at its most impressive, dimension-wise comparable to the present-day Himalayas; but when continental collision between Baltica and Laurentia ceased during Late

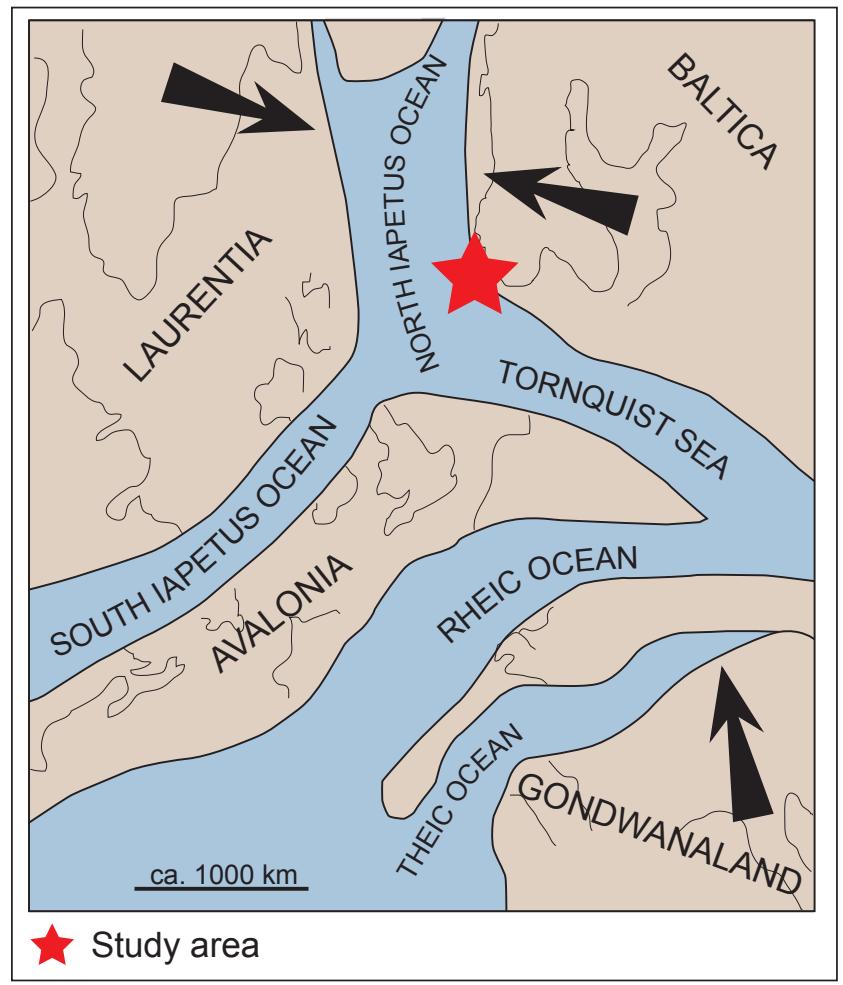

Figure 4. Plate tectonic setting in the present North Sea region in Silurian times (c. $430 \mathrm{Ma}$ ). Arrows suggest approximate plate movements during the Caledonian and Variscan orogenies. The Utsira High location is indicated by the red star. Modified from Rey et al. (1997). 
Silurian to Early Devonian times, the uplift, exhumation and denudation of the mountain chain was rapid (Coward et al., 2003; Fossen et al., 2008; Gee et al., 2008; Gabrielsen et al., 2010). During the Devonian, the North Sea area drifted northwards from around $20^{\circ} \mathrm{S}$ to $15^{\circ} \mathrm{S}$, and sedimentation occurred in a hot, arid and continental setting (Downie, 1998). Devonian (Old Red Sandstone) sedimentation took place in extensionally induced halfgraben basins (Marshall \& Hewett, 2003). Devonian deposits are present in the British Isles and in basins in western Norway, but well data have not yet confirmed a continuous belt across the North Sea (Seranne \& Seguret, 1987; Downie, 1998).

By Early Carboniferous, the North Sea region had drifted northwards to equatorial latitudes, and suffered a change from dry and arid to warm and moist conditions (Glennie \& Underhill, 1998). The Early Carboniferous transgression covered the Devonian landscape and represented a shift from continental-dominated to marinedominated deposition (Glennie \& Underhill, 1998; Bruce \& Stemmerik, 2003). The North Sea region was transgressed progressively from the south, but marine sedimentation was not dominating in the area until Viséan time (Brekke et al., 2001; Bruce \& Stemmerik, 2003). During the Middle Carboniferous, clastic input from the north increased dramatically and sediments from the British Isles show kaolinite to be the predominant clay mineral, possibly due to an increased degree of chemical weathering (Weaver, 1989; Brekke et al., 2001). In Late Carboniferous time, the North Sea region was affected by the emerging fold and thrust belt of the Variscan Orogeny, causing uplift and erosion and also representing a southern source of sediment influx (Besly, 1998; Lundmark et al., 2014). North of the Central Graben, sediments of Carboniferous age have been reported from the Embla and Flora oil fields (Martin et al., 2002; Lundmark et al., 2014) and in well 9/4-5 (www.npd.no). However, Brekke et al. (2001) speculated about the possibility of preserved Carboniferous sediments in pre-Permain half grabens on the Utsira High. The Late Carboniferous marks the closing of the Rheic Ocean and the collision of Gondwanaland with Baltica and Laurentia (Variscan Orogeny), forming the supercontinent of Pangea (Glennie \& Underhill, 1998) (Fig. 4). The study area is positioned close to the tectonically complex triple junction between these three plates, where the eastern branch continues south to the Tornquist-Teisseyre Fault Zone (Fig. 4).

The steady northward drift of the present North Sea region to about $20^{\circ} \mathrm{N}$ of the equator, is reflected in the climate change to dry and arid conditions during the Permian (Glennie \& Underhill, 1998). The closing of the surrounding Caledonian and Variscan oceans, together with the encompassing mountain belts formed topographic and climatic barriers (Coward et al., 2003). The Early Permian collapse of the Variscan Orogen set up extensional fracture systems and widespread volcanism south of the Norwegian Sector (Glennie \& Underhill, 1998). After the extensional event had ended, the Permian basins formed as a result of thermal relaxation of the lithosphere (Ziegler, 1992). The Southern Permian basin occupied the central and southern North Sea area and extended some $1500 \mathrm{~km}$ from eastern England, and it was formed as a landlocked depression where subsidence exceeded sedimentation (Pharaoh et al., 2010). It was separated from the much smaller Northern Permian basin by the Mid North Sea-Ringkøbing-Fyn High. The Northern Permian basin occurred between the Mid North Sea-Ringkøbing-Fyn High and the Shetland and Egersund platforms and was characterised by fault-bounded topography (Glennie \& Underhill, 1998; Coward et al., 2003). The Rotliegend Group was deposited during the Upper Carboniferous to Upper Permian (Glennie, 1995). The dry and arid climate favoured desert lakes and sabkha deposits in the central part of the Northern Permian Basin, while flash floods and ephemeral lakes were probably dominating along the basin margin (Sørensen \& Martinsen, 1987).

The onset of Permo-Triassic rifting is under debate, but it probably lasted into the Middle Triassic (Glennie, 1995; Odinsen et al., 2000). The absence of pre-Permian sediments on structural highs has been attributed to tilting and deep erosion caused by Permo-Triassic lithospheric stretching, resulting in exposed basement rocks and development of large half-grabens (Færseth et al., 1995; Nøttvedt et al., 1995; Gabrielsen et al., 2010). In the Late Permian, the Zechstein Sea transgressed from the north, possibly through a narrow Viking Graben, resulting in the deposition of 2-3 km of Zechstein Group sediments, comprising shales (Kupferschiefer Formation), carbonates and evaporites in the Permian basins (Ziegler, 1992; Taylor, 1998). Permian sediments have been reported from intrahigh grabens on the Utsira High, including the newly drilled Augvald graben (Fig. 2), but are absent across the high suggesting either exposure at the time of deposition, or erosion during the Late Triassic (Laursen et al., 1995; Bergslien, 2002; Coward et al., 2003; Sørlie et al., 2014; www.npd.no).

Acceleration of Early Triassic rifting activity enhanced the N-S-trending graben geometry in the northern North Sea (Ziegler, 1992; Lervik, 2006). At the same time the Zechstein Sea regressed and there was a return to continental deposition represented by a conform, but abrupt, change from carbonate and fine-grained marine, to continental red bed sedimentation (Fisher \& Mudge, 1998). Steel \& Ryseth (1990) and Lervik (2006) suggested that the Utsira High area was land during most of the Triassic, acting as a local source area, supplementing the uplifted Fennoscandian Shield. Further evidence of this is the apparent shift in basin filling styles to the north (sand rich) and south (mud rich) of the high, suggesting that it may have acted as a drainage divide during Early Triassic time (McKie \& Williams, 2009). 
The warm and dry climate established in the Permian lasted until Late Triassic, and peneplanation progressed through the period resulting in the Permo-Triassic denudation surface observed onshore (Lidmar-Bergström, 1993; Fisher \& Mudge, 1998). The basins, formed from thermal subsidence, were filled with thick sedimentary units onlapping basement highs (Fisher \& Mudge, 1998). In the Late Triassic there was a shift to more humid conditions, at a time when the North Sea region was located at around $40^{\circ} \mathrm{N}$ (Lidmar-Bergström, 1982; Preto et al., 2010). The climatic shift was probably connected to the break-up of Pangea, allowing humid air to penetrate further into the continent, and increased $\mathrm{CO}_{2}$ levels as a consequence of volcanic activity (Nøttvedt et al., 2008). From this period and onwards, the exposed Permo-Triassic denudation surface of the Fennoscandian Shield experienced deep weathering (Lidmar-Bergström, 1993), quite possibly extending westward into the North Sea region. Meanwhile, the Tethys Sea had formed to the south and episodic transgressions resulted in marine incursions into the southern North Sea area in Late Triassic. In the southern Utsira High, tidally influenced fluvial channel deposits (Eiriksson Formation in the Statfjord Group) have been encountered in grabens (Sørlie et al., 2014). In the northern North Sea marine facies in the Late Triassic-earliest Jurassic have been attributed to the southern extension of the Boreal Sea (Clemmensen et al., 1980).

In Early Jurassic (Pliensbachian-Sinemurian) time a narrow connection was established between the northern Boreal Sea and the southern Tethys Sea, bounded to the west by the Shetland Platform and to the east by the Fennoscandian Shield (Hamar et al., 1980; Ziegler, 1992; Charnock et al., 2001; Husmo et al., 2002). The Early Jurassic transgression from the north resulted in the deposition of marine shales and sandstones (Dunlin Group), which are preserved to the west in the Viking Graben, to the east on the Horda Platform and on the northernmost part of the Utsira High (well 25/6-1) (Vollset \& Dorè, 1984) (Fig. 3). Prior to the Late Jurassic rifting, the central North Sea was uplifted above sea level due to Toarcian and Aalenian thermal doming (North Sea Dome). Together with a global regression, the consequence was that the seaway connecting the Boreal and Tethys seas was blocked causing deep erosion of Early Jurassic and older sediments (Vail et al., 1977; Ziegler, 1992). Hence, there is a marked unconformity (the midCimmerian or intra-Aalenian unconformity) separating the Lower Jurassic from the Middle and Upper Jurassic in the region (Davies et al., 1999) (Fig. 3).

Synrift development from late Bajocian time in the present Viking Graben area resulted in a reduced influence of the North Sea Dome, transgression from the north and re-establishing of the connection between the Boreal and Tethys seas in Bathonian to Callovian times (Ziegler, 1992; Husmo et al., 2002; Coward et al., 2003). The main Jurassic rifting phase took place during the Callovian to early Kimmeridgian, and was responsible for the main structural setting of the Viking Graben (Coward et al., 2003). Coarse-grained clastics of Callovian and Volgian age in grabens in the southern Utsira High indicate the subaerial exposure of the high through latest Jurassic time (Sørlie et al., 2014). The transition from coarse-grained sedimentation (Draupne sandstone) to fine-grained marine shales (Draupne shale) is probably a result of drowning of the clastic source area (Sørlie et al., 2014) (Fig. 3). From Late Triassic and through the Jurassic the palaeoclimate in southern Fennoscandia was subtropicial and humid (Lidmar-Bergström, 1982). Palaeomaps from Hallam et al. (1993) indicate that the North Sea region was located within the humid belt for most of the Jurassic period. Abbink et al. (2001) recognised four palaeoclimatic phases in the southern North Sea during the Late Jurassic: from Callovian to Early Oxfordian it was relatively cool and humid which changed to a warmer and drier climate from Mid Oxfordian to Early Kimmeridgian. Arid conditions prevailed from the Late Kimmeridgian to Early Ryazanian when there was a shift back to a humid subtropical setting.

In the southern Viking Graben, rifting ended in Early Cretaceous and can be associated with rapid subsidence and burial (Ziegler, 1992; Nøttvedt et al., 2008). The deposition of an Early Cretaceous shallow-marine facies across the Utsira High marks the definitive end of subaerial exposure (Fig. 3). Since then the Utsira High has gradually subsided to its present depth.

\section{Sampling procedures and methods}

In this study, eighteen basement cores from the Utsira High are in focus. Core viewing was performed at Weatherford Labs, Sandnes, and the Norwegian Petroleum Directorate, Stavanger, in 2012 and 2013. The recovered core material (from basement) in these wells varies in length between 0.5 and $47 \mathrm{~m}$. In wells where the overlying sedimentary strata have been cored, these intervals have also been included in the study. In total, more than 160 samples have been collected for mineralogical and petrographical analyses including optical microscopy, scanning electron microscope (SEM) and X-ray diffraction (XRD) analysis (bulk and $<2 \mu \mathrm{m}$ fraction).

During core inspection, the degree of alteration of the crystalline basement was classified according to a modified version of the procedure proposed by the International Society for Rock Mechanics (ISRM, 1978). The classification uses a scale from W1-W5, where W1 (fresh): no visible signs of material alteration, W2 (slightly altered): discolouration of discontinuity surfaces, W3 (moderately altered): less than half of the rock material is decomposed, W4 (highly altered): more than half of the rock material is decomposed, and W5 


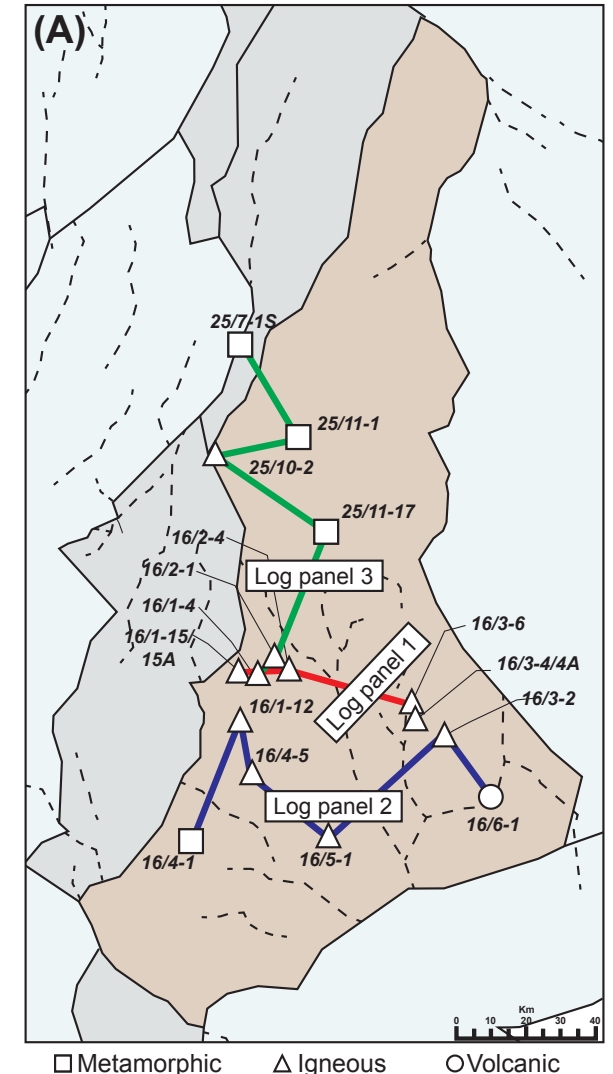

(B)
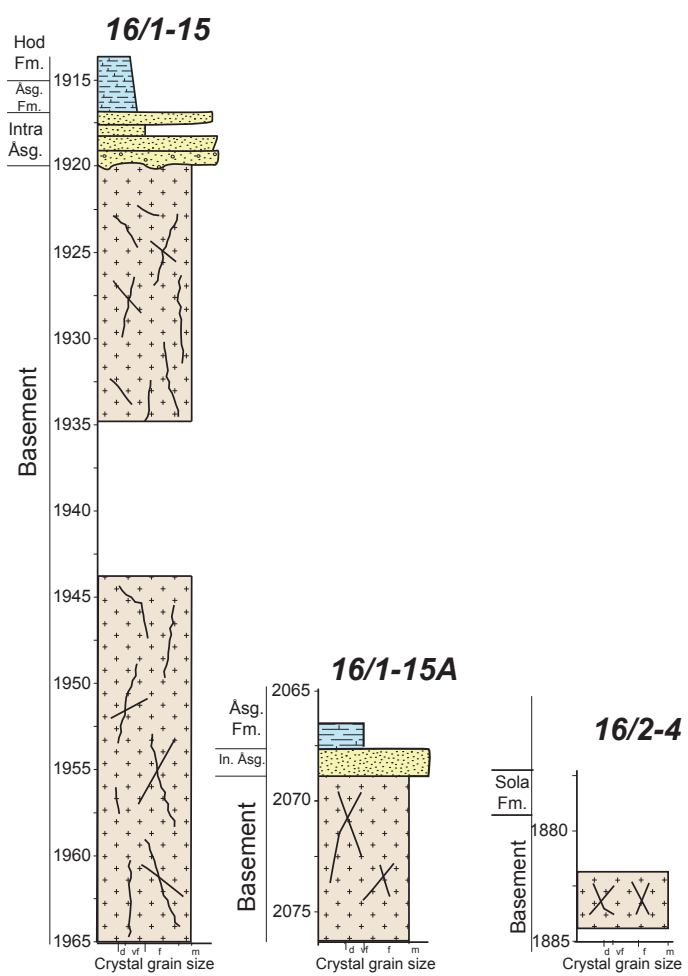
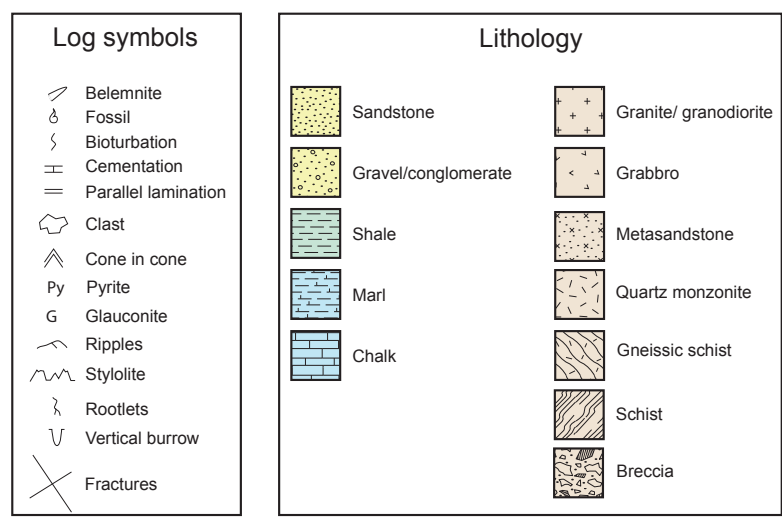

Figure 5. Sedimentary logs from the studied wells presented as two E-W log panels and one N-S log panel showing the main basement lithologies and basal sedimentary units. (A) Well map showing the distribution of igneous, volcanic and metamorphic basement rocks on the Utsira High, the three log panels (log panel 1, log panel 2 and log panel 3), and legend. (B) Log panel 1 (16/1-15, 16/1-15A, 16/2-4, 16/3-6, 16/3-4 and 16/3-4A). (C) Log panel 2 (16/4-1,16/1-12, 16/4-5, 16/5-1,16/3-2 and 16/6-1). (D) Log panel 3 (16/1-4, 16/2-1, 25/11-17, 25/10-2R, 25/11-1 and 25/71S). Detailed sedimentary logs and sketches are included as Electronic Supplements 1-16. 
(C)

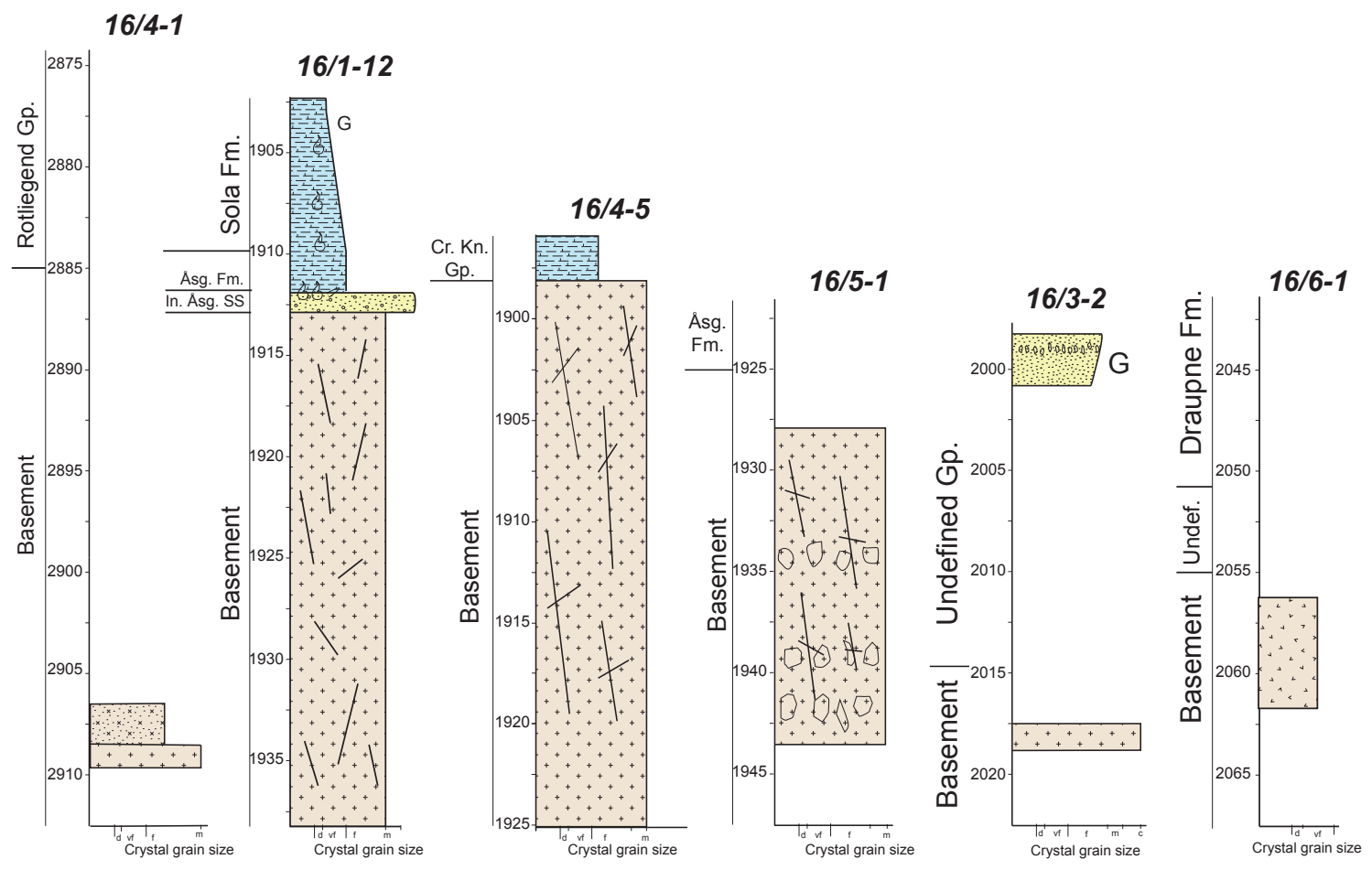

(D)

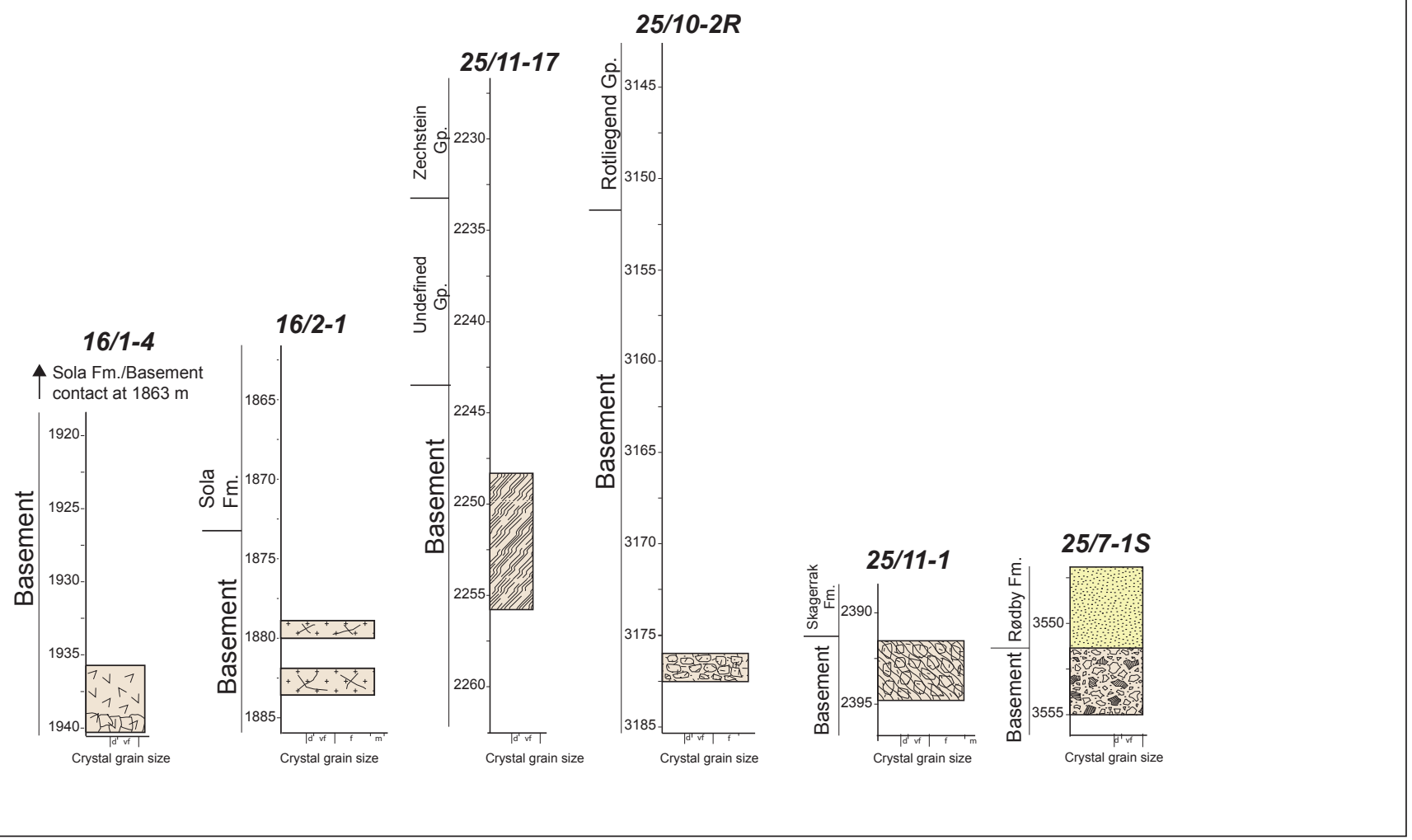

(completely altered): all rock is decomposed, but original rock structure is still largely intact. All core depths in this study are reported as measured depths (MD). Sedimentary logs from all wells are presented in three log panels
(Fig. 5). Detailed sedimentary logs and sketches from $16 / 1-15$ and $16 / 3-4$ are included in the paper, while logs and sketches from all the other wells are included as Electronic Supplements 1-16. 
Optical microscopy and point counting (400 counts) were carried out with a Nikon Labophot-Pol petrographic microscope and Swift Model F automatic point counter. Point counting was performed on the samples believed to be the least altered, and thus have a composition closest to the protolith. Subsequently, rock composition was plotted on standard QAP (Quartz-Alkali-feldspar-Plagioclase) rock classification diagrams (Le Maitre \& Bateman, 1989). Key samples were investigated under SEM-EDS (JEOL JSM-6460LV, with a LINK INCA Energy 300 (EDS)).

XRD analyses (crushed bulk samples and clay fraction $(<2 \mu \mathrm{m}))$ were carried out on a Bruker D8 advanced (40 $\mathrm{kV}$ and $40 \mathrm{~mA}$ ) diffractometer with Lynxeye $\mathrm{XE}$ High-Resolution Energy Dispersive $1 D$ Detector, using $\mathrm{CuK \alpha}$ radiation. All samples underwent XRD analysis in order to observe how the rock composition changed as a result of alteration (Electronic Supplement 1). Phase identification was conducted with the software Diffrac. EVA according to methods by Moore \& Reynolds (1997). The Rietveld method, using the entire peak profile (Rietveld, 1969), was applied for quantification using Siroquant. The quantification set-up followed the five-stage procedure suggested by Hillier (2000), with an additional sixth stage with six cycles on orientation with a damping factor of 0.4 . The $<2 \mu \mathrm{m}$ fraction was analysed four times: air-dried, treated with ethylene vapour for 24 hours, heated to $350^{\circ} \mathrm{C}$ for about 1 hour and, finally, heated to $550^{\circ} \mathrm{C}$ for about 1 hour. A detailed clay mineralogical analysis will be presented in a later publication (Riber et al., in prep.).

\section{Results}

The studied wells are grouped in two E-W log panels from the southern Utsira High and one N-S log panel from the northern Utsira High (Fig. 5A), and they will be presented accordingly (Fig. 5B-D).

\section{6/1-15 (Fig. 6)}

The well is located on the western side of the Utsira High in the northern part of the Edvard Grieg Field, in an area formerly known as the Tellus prospect (Fig. 2). Around $3 \mathrm{~m}$ of the Cretaceous Åsgard Formation sandstone (informal unit) are overlying fractured and severely altered granitic basement. The sandstone is abruptly succeeded by Åsgard Formation marls at $1917 \mathrm{~m}$ depth. Monzogranitic/granodioritic basement is reached at $1920 \mathrm{~m}$ and has been cored down to $1973.20 \mathrm{~m}$ with a total recovery of $47 \mathrm{~m}$ (Figs. 6, 7; Table 1). Quartz, microcline and sericitised plagioclase make up the main minerals, with lesser amounts of biotite, chlorite and pyrite present (Tables 1,2).

On visual inspection, basement appears highly altered in intervals that increase in frequency and thickness upwards (Figs. 6, 8A). The first $2 \mathrm{~m}$ above core base $(1973.20 \mathrm{~m}$ ) are made up of friable and fractured granodiorite, classified between W2 and W3 in the degree of alteration scale (Fig. 6). This interval is separated from a less altered upper interval by a $20 \mathrm{~cm}$-thick, dark, fine-grained basalt. Up to a depth of $1943 \mathrm{~m}$, short intervals of no more than 1 $\mathrm{m}$ of altered rock (W3/4) interrupt every $2-3 \mathrm{~m}$ in an otherwise less (W2) altered bedrock (Fig. 6).

In optical microscope analysis from the 1973.16-1943.00 $\mathrm{m}$ interval, alteration of individual mineral grains is most pronounced in plagioclase and to a lesser degree in biotite, chlorite and microcline. Plagioclase crystals are typically highly sericitised and with concentric zonation. Sericitisation is at times profound enough to obscure the characteristic polysynthetic twinning of the mineral. Plagioclase alteration commences with the dissolution of the mineral core, which proceeds to affect the whole crystal in the more altered samples. Dissolution vugs are mainly filled with a high-birefringence, fine-grained and micaeous secondary phase, which by SEM-EDS analysis has been identified as an illite-like mineral. XRD clay fraction analysis has revealed the presence of a smectitic clay mineral. Under the SEM, smectitic clays have been observed within dissolved plagioclase (e.g., from 1972.50 $\mathrm{m})$. The amount of smectitic clay is highest in the lower samples and decreases in the stratigraphically higher samples.

Biotite has been observed under the optical microscope, displaying a brownish colour and distinct pleochroism, and its presence has been confirmed by SEM-EDS analysis. In the samples from the lower part, we observed examples of biotite displaying both straight (Fig. 9A) and sinuous cleavage. Chloritisation of the biotite has taken place and associated with this process, rutile, apatite, (secondary) plagioclase and euhedral (secondary) $\mathrm{K}$-feldspar have precipitated between the crystal laths. In the more altered samples, biotite appears splayed and dissolution has evidently taken place along grain fringes and cleavage planes. Dissolution pits are either open or occupied by clay-sized minerals, identified as chlorite by SEM-EDS analysis.

Microfractures both across grain contacts and through grains are observed to be either open or filled with clay minerals (chlorite and illite) and authigenic K-feldspar.

At $1943 \mathrm{~m}$ depth there is a gap in the core for about $9 \mathrm{~m}$ (Fig. 6). Above the gap, the same trend of alteration continues for the first $5 \mathrm{~m}$ from a core depth $1934 \mathrm{~m}$ and upwards. The top $9 \mathrm{~m}$ represent an upwards-increasing trend of arenisation, where the granite is totally disintegrated into a grus type of lithology (Fig. 8A). Even in the most severely altered intervals (up to W4/5) the rock appears to be dominated by mechanical fragmentation, with only minor compositional change. Clay is not observed in hand specimens. Even in the most altered parts of the 


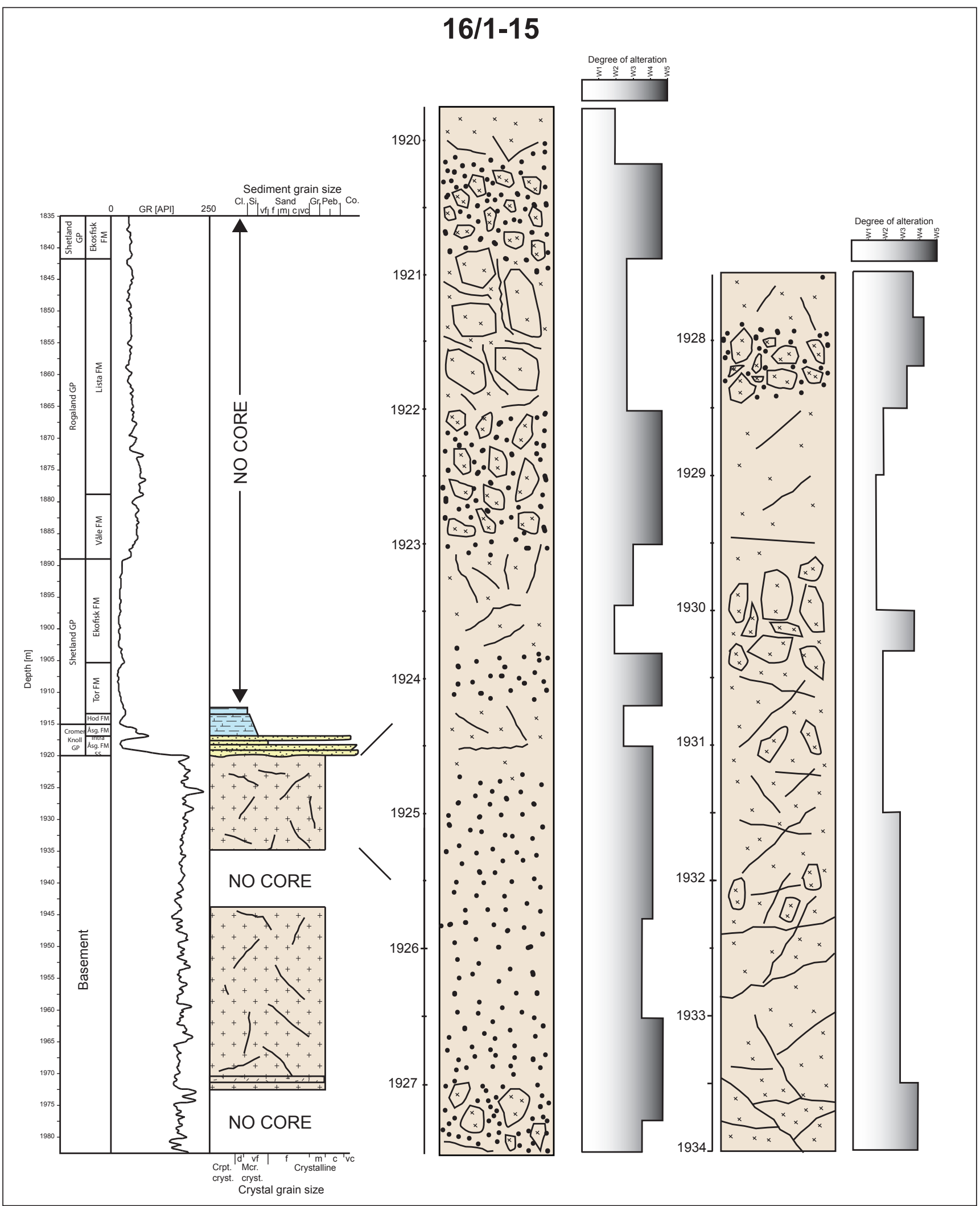

Figure 6. Sedimentary log and basement sketch from well 16/1-15 showing the degree of weathering (W1-W5) of a medium-grained monzogranite.

core the total clay amount remains low $(<5 \%)$. The clay association includes smectite, chlorite, fine-grained mica/ illite and kaolinite (Table 1).
Fig. 10 suggests that there is a correlation between increasing amounts of clay and decreasing amounts of plagioclase and biotite, while no decrease in the $\mathrm{K}$-feldspar and quartz content is observed. 


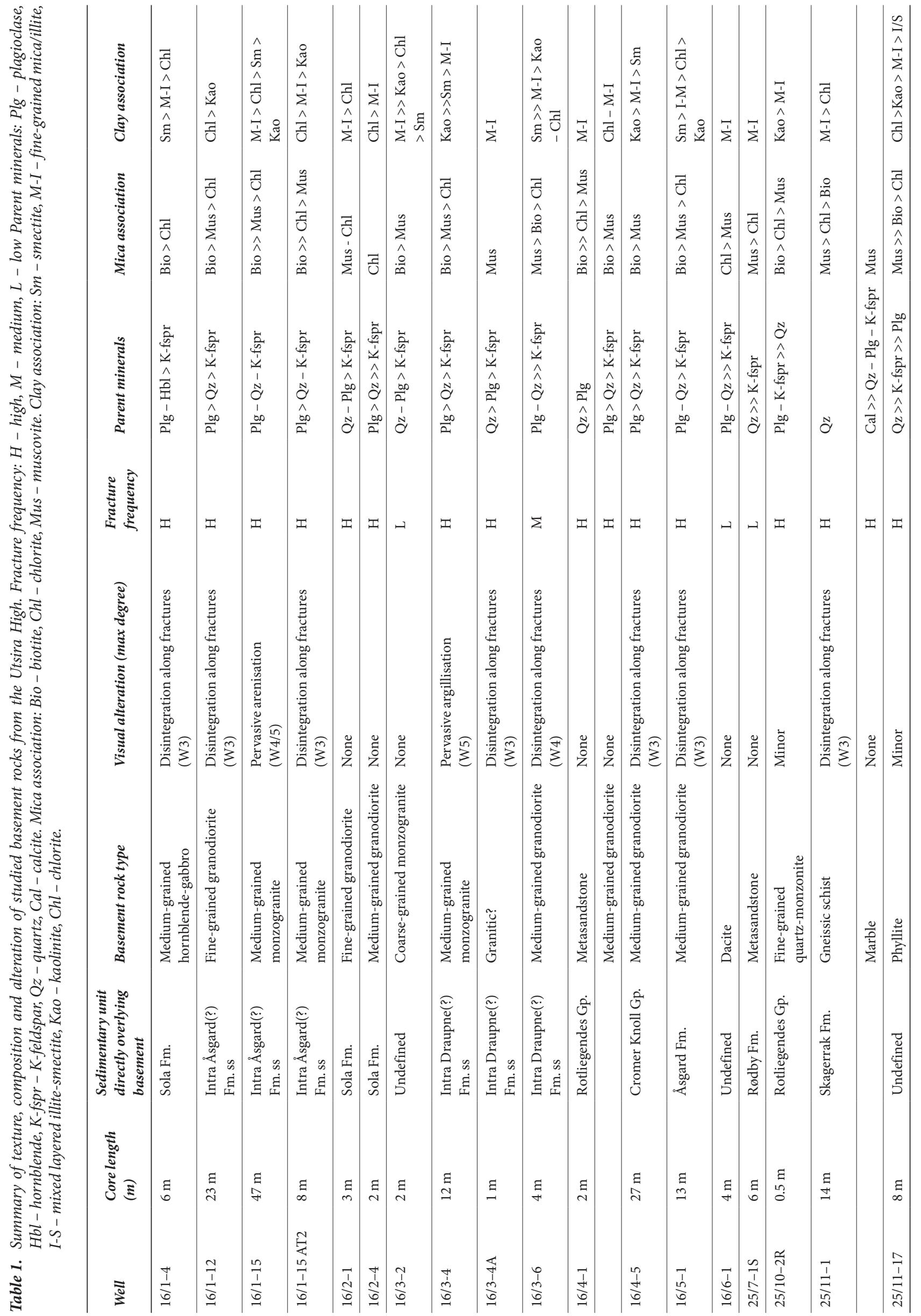




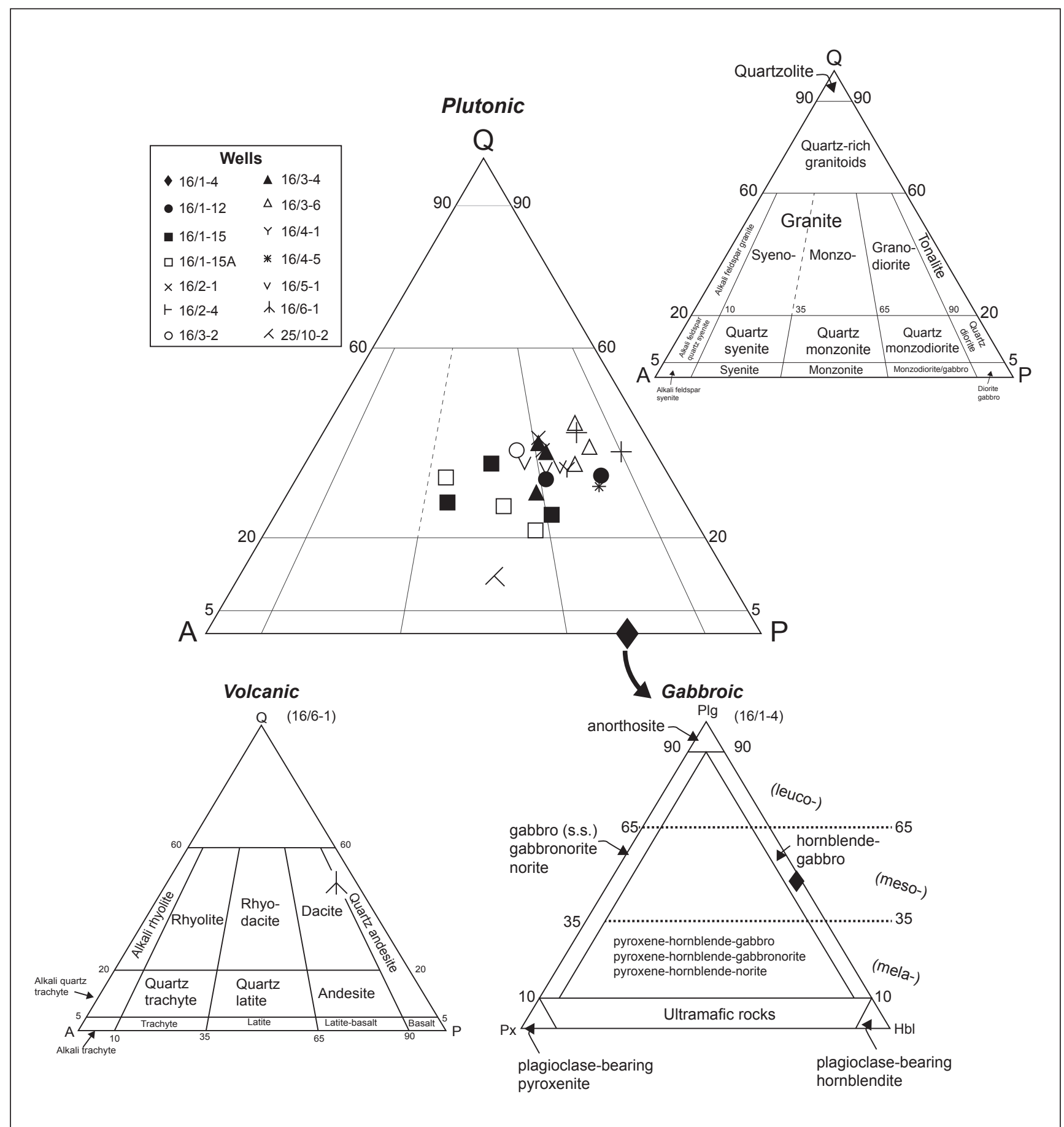

Figure 7. QAP diagram (Le Maitre \& Bateman, 1989) displaying basement compositions for the plutonic and volcanic rocks encountered in the study. The detailed gabbroic and volcanic compositions for 16/1-4 and 16/6-1 are displayed in separate diagrams.

\section{6/1-15A (Electronic Supplement 1)}

$16 / 1-15 \mathrm{~A}$ was drilled as a sidetrack to $16 / 1-15$ and reached the top basement surface about $0.7 \mathrm{~km}$ east of the entry well (16/1-15). A sharp contact at around $2069 \mathrm{~m}$ core depth marks the boundary between top basement and the Åsgard Formation sandstone (informal unit) comprising an oil-stained, coarse- to fine-grained sandstone, where the majority of grains consist of broken shell fragments. Oil staining is absent in the upper 15 $\mathrm{cm}$ of the about $1 \mathrm{~m}$-thick sandstone, where there is an abrupt change to a greenish marl marking the base of the Åsgard Formation (Fig. 5B). There is a gradual upwards change in colour from green to red and finally to white chalk at the top of the core at $2066 \mathrm{~m}$ (Fig. 5B).

Basement was cored from $2069 \mathrm{~m}$ and down to $2076.26 \mathrm{~m}$ depth, and can be classified by modal analysis as mediumgrained equigranular monzogranite (Fig. 7; Table 2). Visual core inspection indicated that macroscopic 


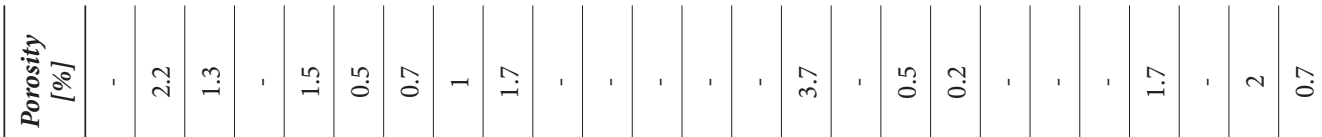

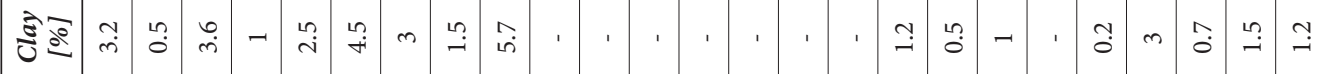
ฐँ

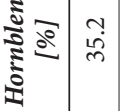
芯

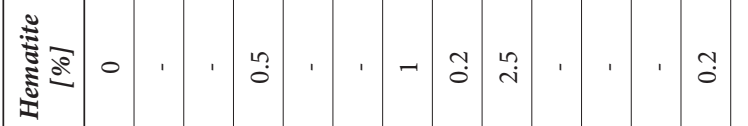

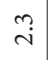

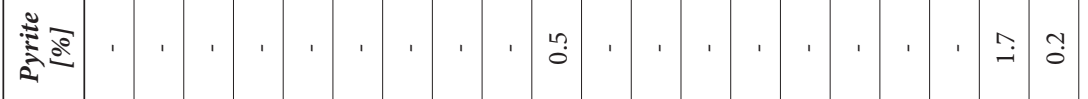

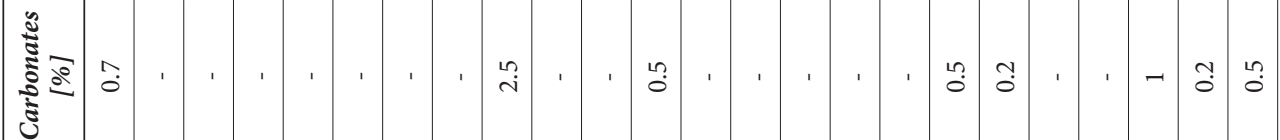

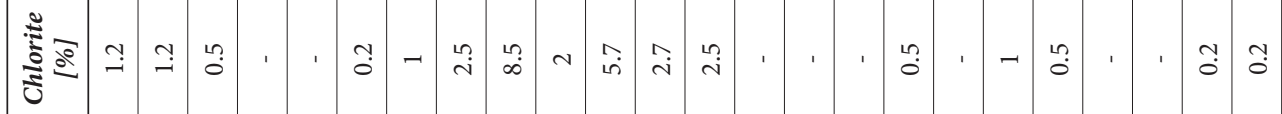

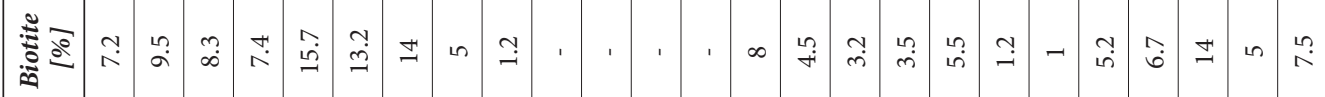

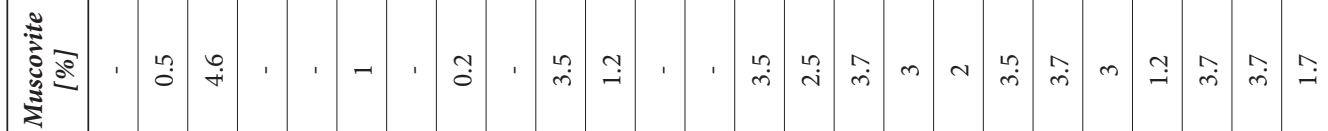

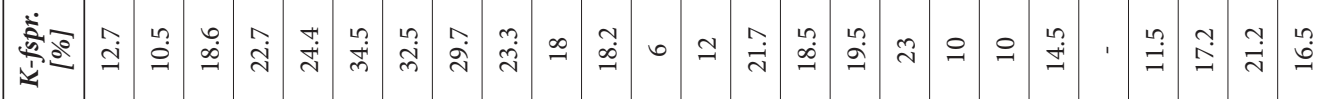

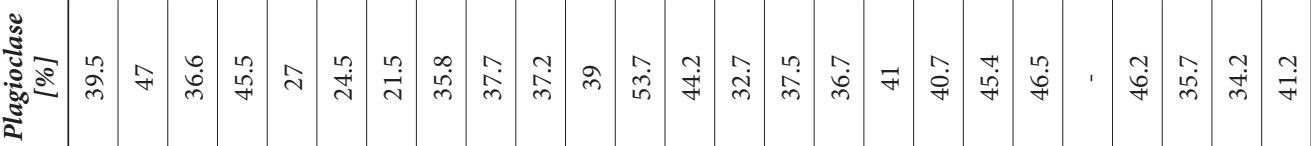

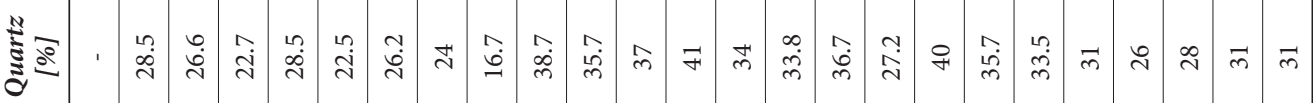

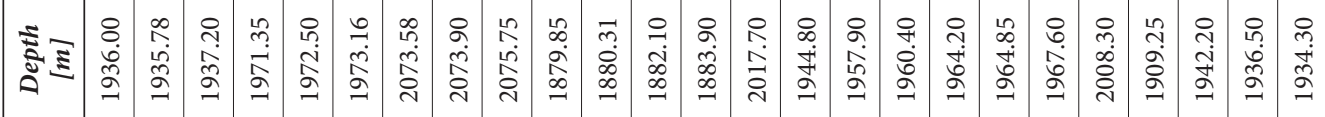

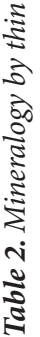

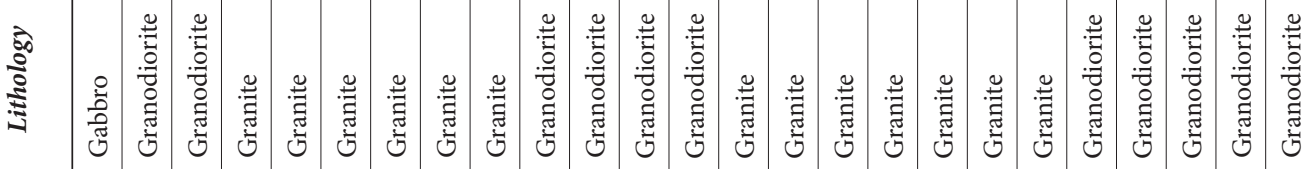

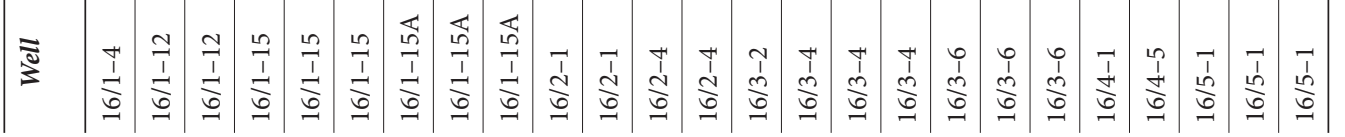




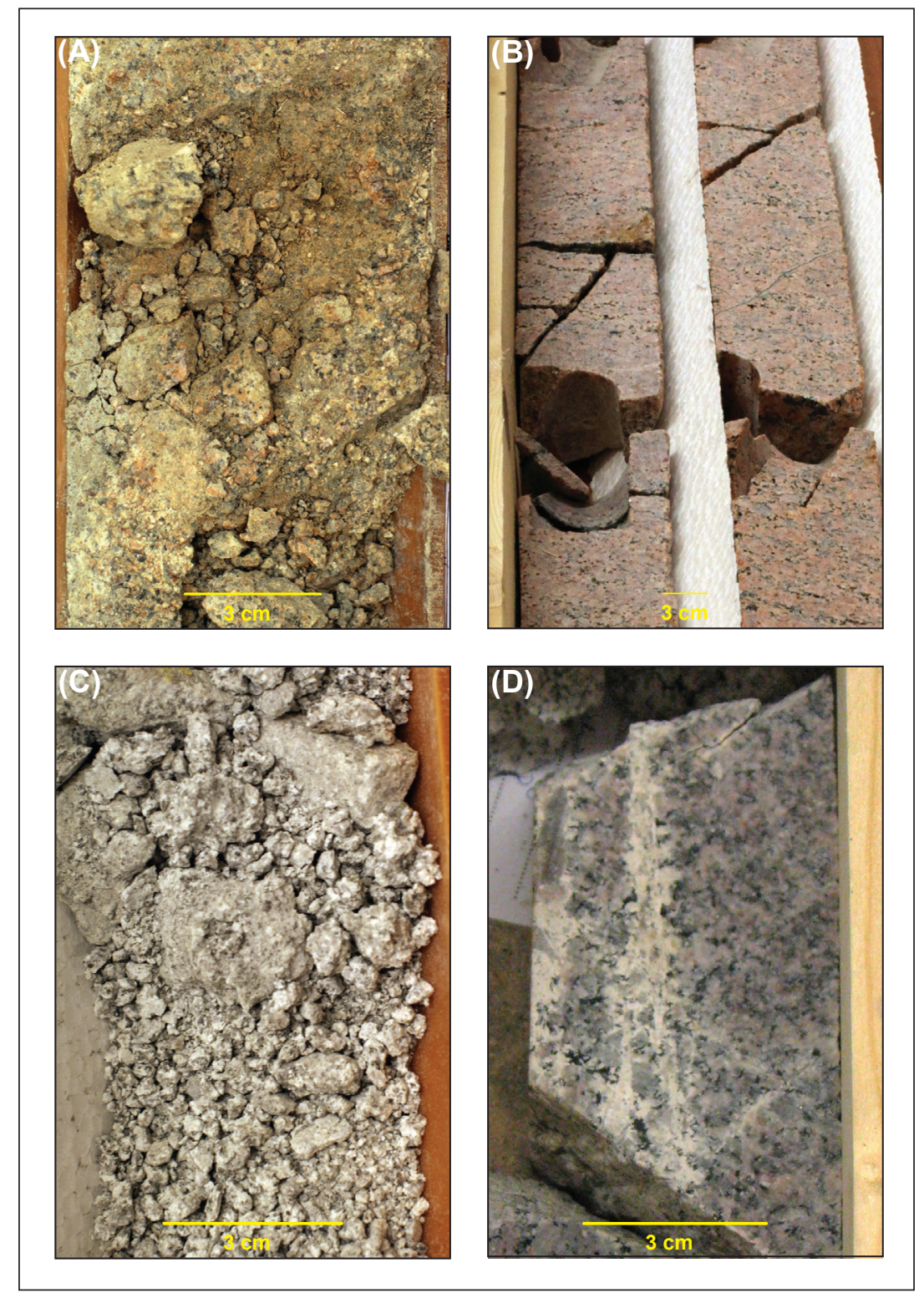

Figure 8. Selection of core pictures displaying the different kinds of alteration observed in macroscopic view. (A) 16/1-15: pervasive arenisation. (B) 16/2-4: fracturing without visible disintegration. (C) 16/3-4: pervasive argillisation. (D) 16/5-1: disintegration along fracture.

alteration of the granite appears to be restricted to fractures, while the rest of the rock is unaltered except for a slight discoloration. Along fracture planes, the rock is friable (W2/3) and in places coated with clay material.

The granite consists of quartz, K-feldspar, plagioclase, biotite and minor amounts of muscovite, chlorite, hematite, dolomite and calcite (Table 1). Plagioclase displays a concentric zonation and minor sericitisation focused in the cores of the mineral grains. Small dissolution cavities in plagioclase grains are observed in SEM, appearing either as an intragranular porosity or filled with chloritic clay. Biotite is the other mineral showing minor signs of alteration. Transformation and dissolution have mainly taken place on the edges of the mineral, leaving the inner part unchanged. Chlorite is observed as a secondary clay mineral in close vicinity to the biotite, but also as transformed biotite along 001 planes at the fringes of grains. Minor amounts of rutile and apatite are found associated with chlorite within and around the biotite.

In addition to chlorite, $\mathrm{XRD}$ analysis has revealed the presence of small amounts of kaolinite but it was not recognised in SEM. A slightly higher degree of plagioclase and biotite dissolution is observed in the uppermost part, manifested by obscured polysynthetic twinning. The existence of calcite and dolomite has been revealed in optical microscope and SEM-EDS analyses.

\section{6/2-4 (Electronic Supplement 2)}

The well was drilled in the west-central part of the Utsira High (Fig. 2). Two metres of the Mid Aptian-Early Albian Sola Formation have been reported resting on basement, with the boundary reached at $1879 \mathrm{~m}$ depth 
(www.npd.no) (Fig. 5B). The basement/sediment contact was not cored, and only $2 \mathrm{~m}$ of basement core were collected, from the 1882-1883.9 m interval (Fig. 5B). Modal analysis classifies the rock as a medium-grained, inequigranular, plagioclase-rich granodiorite, with feldspar and quartz phenocrysts up to $4 \mathrm{~mm}$ (Fig. 7; Table 2).

Fractures are frequent, with two distinct directions typically intersecting at $60^{\circ}$ and $120^{\circ}$ (Fig. 8B). No obvious signs of alteration occur along fracture planes, nor are they slickensided. Small pores are observed on the surface of the rock, probably related to chlorite/biotite dissolution.
The rock is made up of plagioclase, quartz and minor amounts of K-feldspar, chlorite, pyrite, muscovite and calcite as determined by modal analysis. Biotite was not observed under the optical microscope, but small patches within chlorite were confirmed by SEM-EDS, suggesting that chloritisation of biotite had taken place. Rutile is found associated with chlorite, while pyrite is observed in dissolution cavities near the intact mineral. Plagioclase has an albitic composition with minor sericitisation. No albite dissolution was observed (Fig. 9B) and XRD clay fraction analysis reveals only traces of chlorite and finegrained mica/illite (Table 1).
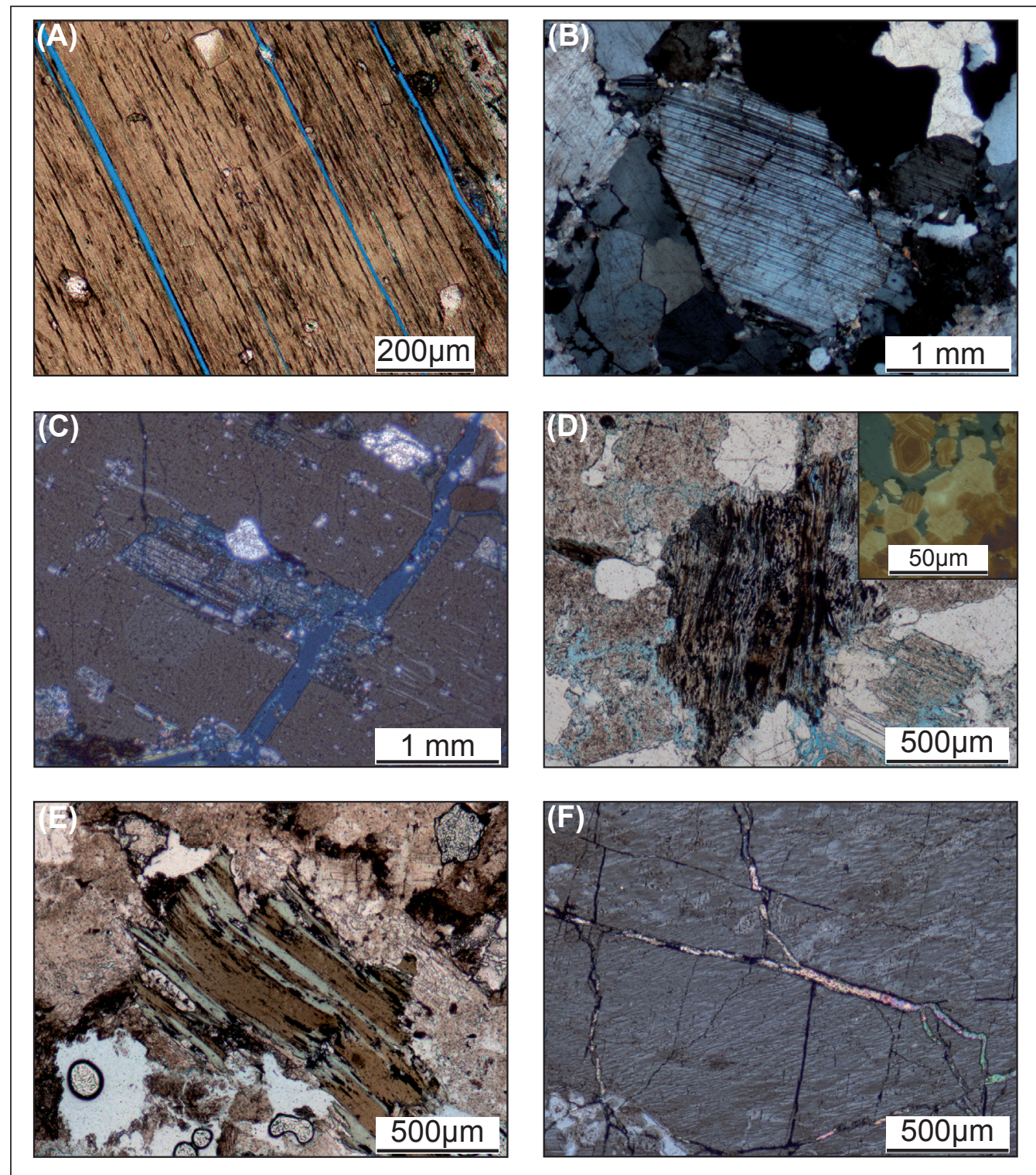

Figure 9. Set of photomicrographs displaying different alteration features. (A) Straight cleavage, but widening of wafers suggests minor alteration of biotite, from 16/1-15 at level $1972.50 \mathrm{~m}$. (B) Polysynthetic twinning in a minor altered plagioclase crystal in 16/2-4 at level 1882.10 m. (C) Intragranular microfracture, crossing the outer K-feldspar and inner plagioclase core. Dissolution of plagioclase and precipitation of kaolinite have occurred, from 16/3-4 at level $1944.40 \mathrm{~m}$. (D) Severely altered biotite grain surrounded by altered plagioclase. Note the sinuous cleavage. The inset shows associated pyrite crystals formed within widened biotite cleavage, in reflected light, from 16/3-4 from level 1944.40. (E) Example of how the biotite is depleted of $K+$ along the 001 plane and approaches a chloritic composition associated with the pale green colour, from 16/3-6 at level 1964.80 m. (F) Calcite precipitated in intragranular microfractures in mantled K-feldspar, from 25/10-2R at level $3177.55 \mathrm{~m}$. 


\section{6/3-6 (Electronic Supplement 3)}

Well 16/3-6 was drilled about $1 \mathrm{~km}$ northwest of 16/3-4 on the eastern flank of the Johan Svedrup field (Fig. 2). Very coarse-grained sandstone is observed to conformably succeed a $70 \mathrm{~cm}$ interval of reworked basement with a base at $1963.50 \mathrm{~m}$ (Fig. 5B). Subjacent to this is the top of the altered and fractured basement section which was cored down to a depth of $1967.60 \mathrm{~m}$. The sandstone fines upwards to around $1954 \mathrm{~m}$ and is characterised by several cemented intervals that are believed to be composed of clasts. A medium-grained sandstone is present up to $1938 \mathrm{~m}$ where it ends in a condensed section and is succeeded by a black shale (Fig. 5B).

The least altered parts of the basement rock can be classified as a medium-grained, equigranular granodiorite (Fig. 7; Table 2). The rock is dominated by plagioclase, quartz and subordinate K-feldspar. Muscovite is the most abundant of the micas, but small amounts of biotite and chlorite are also present. In addition, traces of calcite, pyrite and apatite are observed. Secondary clay minerals in the form of smectite and fine-grained mica/illite are also present (Table 1).

At the base of the $4.5 \mathrm{~m}$ cored basement interval, the rock is characterised by horizontal and vertical joints, alternating open or closed. In hand specimens, no obvious signs of alteration are noted, but under the optical microscope biotite is observed beginning to splay and experiencing a slight colour change. Plagioclase, apart from being highly sericitised, is only subject to minor alteration at this level. Moving upwards in the core there is no obvious increasing trend and alteration does not appear to be pervasive. Disintegration of the rock is concentrated along open fractures where it can reach $\mathrm{W} 4$ on the alteration scale. A sample from one of these fractures revealed an XRD composition comprising smectite $>>$ fine-grained mica/ illite $>$ kaolinite $>$ chlorite (Table 1). But the total clay makes up no more than $3 \%$ of the total rock volume. In the SEM, the smectite has only been observed in dissolution pits within plagioclase $\left(\mathrm{Ab}_{70-50}\right)$ (Fig. 11E). Biotite remains relatively intact, with some pyrite precipitated along cleavages and splaying restricted to grain fringes. Also observed in the SEM is the presence of thin calcitic veins precipitated along the tips of biotite and also through plagioclase crystals. The top of the basement core consists of basement clasts in a coarse-grained sand matrix and is interpreted to represent the reworking of fragmented basement rocks. There appears to be a correlation between the increase in clay content and a decrease in the amount of plagioclase and biotite (Fig. 10A).

\section{6/3-4 (Fig. 12)}

The well is located at the Avaldsnes high as part of the Johan Sverdrup field (Fig. 2). The sediment/basement contact was reached at $1940.70 \mathrm{~m}$, where pebbly sandstone overlies highly fragmented bedrock (Fig. 12). A notable feature of the contact is the presence of a basaltic rock clast, exceeding the width of the core. The sandstone

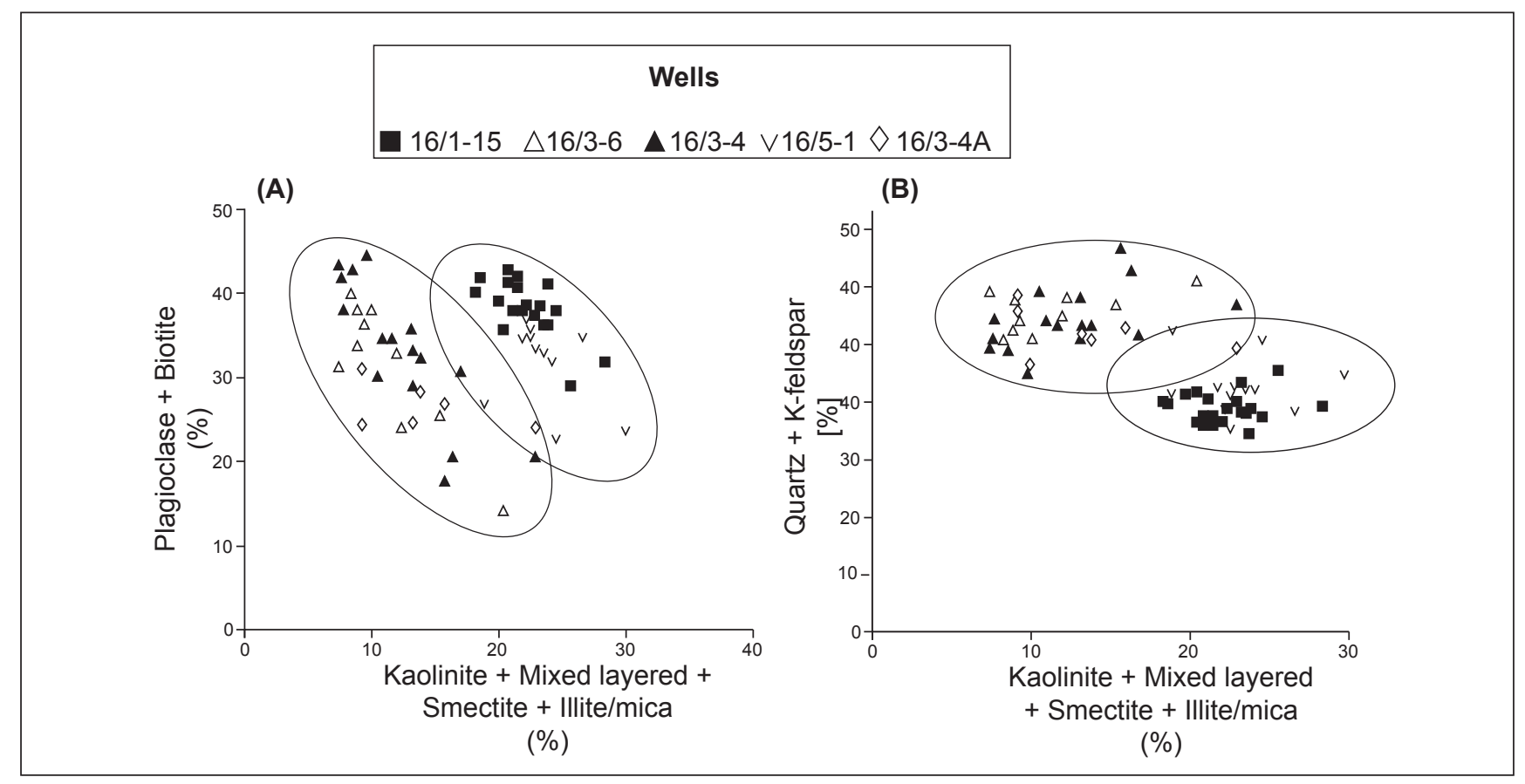

Figure 10. XRD results from weathered cores. (A) The plagioclase + biotite content is plotted against the percentage of total clays. As the clay content increases the plagioclase and biotite content decreases. (B) The quartz + K-feldspar content is plotted against the total clay content. There is no correlation here between the increase in clay and the quartz $+K$-feldspar content 
is oil stained and reacts to $\mathrm{HCl}$ treatment. About $13.5 \mathrm{~m}$ of upward-fining sandstone ends in a condensed interval, which is followed by black shales (Fig. 12).

Basement has been cored down to $1960.60 \mathrm{~m}$ but the interval between 1946.50 and 1955.10 is missing (Fig. 12). Hence, about $11.5 \mathrm{~m}$ of crystalline bedrock is available as core. The basement has been classified as medium grained, equigranular and of monzogranitic to granodioritic composition (Figs. 7, 13A; Table 2). In the least altered samples, plagioclase dominates over quartz and microcline. Biotite and muscovite are present in about equal amounts in addition to traces of calcite, chlorite, pyrite, rutile and apatite. The presence of clay minerals and evidence of dissolution in the least altered samples, suggest that the well did not reach the unaltered protolith.

In the lowermost part of the cored section the rock is broken into pieces, but hand specimens show that it has not otherwise been subject to extensive alteration (Fig. 12). Optical microscope observations reveal plagioclase $\left(A b_{90-70}\right)$ to be present both as individual crystals and in the cores of mantled K-feldspars. The plagioclase is highly sericitised, has a hazy appearance and shows discontinuous zoning. Small dissolution pits within the crystal accommodate clay minerals which have been identified by both SEM-EDS and XRD analyses as kaolinite, smectitic clays and chlorite. Cleavage planes in biotite are only moderately splayed, with main dissolution at the grain fringes (Fig. 11B). The resulting pore space has been filled by clay minerals, for example kaolinite. Chloritisation of biotite is observed. Authigenic pyrite and occasionally rutile have been observed as crystals within the chlorite-like mineral along biotite cleavages. At this depth, kaolinite is the dominant clay mineral, but only slightly exceeds the smectitic clay content. Up to the core break at $1955.10 \mathrm{~m}$, basement is classified as alteration W1/2 (Fig. 12). Clay content is generally low, no higher than $3 \%$.

The interval above the core break, from depth $1946.50 \mathrm{~m}$ and up to $1940.70 \mathrm{~m}$, displays different features. Immediately above the break the rock is beginning to decompose and can easily be broken by hand (Fig. 12). Whitecoloured clay material is observed coating the rock. At this level, the degree of alteration has been classified as $\mathrm{W} 3 / 4$. Upwards there is a general trend for the rock to become increasingly friable, with enhancing amounts of clay. From $1944 \mathrm{~m}$ and upwards the rock is classified as W4/5, though with a short interval between 1942.30 and $1943 \mathrm{~m}$ with less alteration (W3/4) (Fig. 8C). The increasing alteration is also evident at microscale, where plagioclase appears highly dissolved, with kaolinite precipitated in the resulting pore spaces (Figs. 9C, 11G). Biotite is splayed with sinuous cleavage (Figs. 9D, 11H). Incipient pseudomorphic transformation of biotite to kaolinite is observed along the splayed crystal laths. Kaolinite is the dominant clay mineral as observed by
XRD and SEM-EDS analysis, with minor amounts of fine-grained mica/illite (Table 1). XRD did not reveal any smectitic clays in the entire upper section. Total clay in the upper part exceeds $15 \%$ of the total rock. As displayed in Fig. 10A, the secondary clay most likely formed at the expense of plagioclase and biotite, whereas no correlation was found between formation of clay and the quartz and K-feldspar content (Fig. 10B).

\section{6/3-4A (Electronic Supplement 4)}

This is a sidetrack from $16 / 3-4$, and reached the top basement surface about $0.5 \mathrm{~km}$ west of the entry well (16/3-4) and upflank towards the high (Fig. 2). In well 16/3-4A, a $30 \mathrm{~cm}$-thick conglomerate represents the boundary between basement and sediments at a depth of $2080.20 \mathrm{~m}$. Above the conglomerate, an upwards-fining sandstone is present up to $2075 \mathrm{~m}$ where a condensed section marks the boundary to the overlying black shales (Fig. 5B).

About $2.20 \mathrm{~m}$ of cored basement has been recovered. The high degree of alteration in the rock makes mineral estimation by optical microscope complicated, but rock composition has been determined by bulk XRD (Fig. $14 \mathrm{C}$ ). The rock is made up by quartz, plagioclase and subordinate K-feldspar. Muscovite/illite constitutes up to $16 \%$ of the total rock. Carbonates are common and dolomite is always more abundant than calcite. Iron sulphide is present as pyrite through the entire cored section, while marcasite was identified at level $2081.43 \mathrm{~m}$. The high degree of alteration, especially the transformation of plagioclase to sericite, makes determination of protolith composition difficult. However, the presence of quartz, K-feldspar, plagioclase pseudomorphs and absence of preferred orientation of elongated micas point to a granitic origin (Table 1).

In the core, the rock is highly brecciated and partly cemented by a greenish-yellow matrix. Close to fractures, the rock is easily broken by hand, reaching up to W3 on the alteration scale (Table 1). The alteration appears to be more connected to fractures than to depth, but a vertical trend cannot be excluded since only $2.20 \mathrm{~m}$ of core is available.

In the SEM, no plagioclase dissolution was observed, only the patchy transformation to sericite and Mg-rich illite. Biotite has experienced widening along the 001 planes with concomitant precipitation of calcite and associated iron sulphides. The association of carbonates (calcite and dolomite) and iron sulphides is commonly observed in microfractures. XRD from the $<2 \mu \mathrm{m}$ fraction shows fine-grained mica/illite as the only clay-sized mineral present, probably representing the sericite and the $\mathrm{Mg}$ rich illite. The mineral relations in Fig. 10 illustrate that the fine-grained material (sericite and clay) formed at the expense of plagioclase and biotite. 


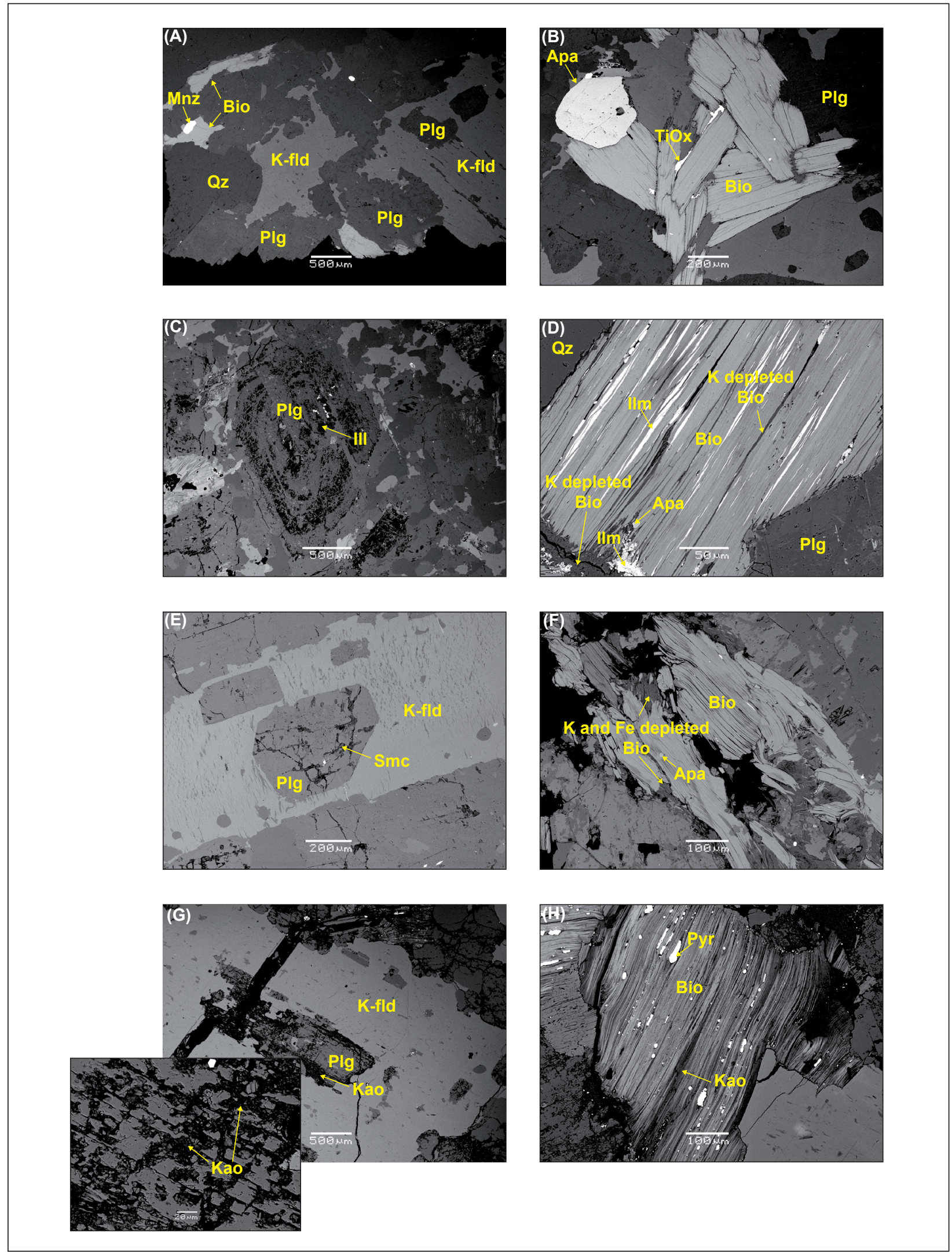

Figure 11. Different degrees of plagioclase and biotite alteration in SEM views of thin-sections. (A) Example of minor alteration from 16/3-2 at level $2017.50 \mathrm{~m}$. (B) Minor alteration in biotite. Associated apatite and TiOx from 16/3-4 at level $1957.90 \mathrm{~m}$. (C) Preferred dissolution in a zoned plagioclase grain from 16/1-12 at level 1937.2 m. (D) Widening of the 001 planes in biotite. Composition approaches that of chlorite close to the cleavage planes, from 16/4-1 at level $2008.3 \mathrm{~m}$. (E) K-feldspar with plagioclase core. Note commencing dissolution within plagioclase and resulting precipitation of smectite from 16/3-6 at level 1964.80. (F) Highly altered biotite. Note the dissolution vugs, from 16/5-1 at level $1935.50 \mathrm{~m}$. (G) Dissolution of plagioclase within a K-feldspar crystal. Inset shows the precipitation of kaolinite, from 16/3-4 at level $1944.40 \mathrm{~m}$. (H) Sinuous cleavage and precipitation of kaolinite and pyrite in highly altered biotite, from 16/3-4 at level 1944.10 m. Abbreviations: Kao - kaolinite, Mnz - monazite, Bio - biotite, Apa apatite, TiOx - titanium oxide, Ilm - illmenite, Ill - illite, Qz-quartz, Plg-plagioclase, K-fld - K-feldspar, Cal - calcite. 


\section{6/4-1 (Electronic Supplement 5)}

The well was drilled on the southwestern margin of the Utsira High in a fault zone on the top of the hanging wall (Fig. 2) (Jackson et al., 2010). Basement is located at $2885 \mathrm{~m}$ and is overlain by a $264 \mathrm{~m}$-thick package of Rotliegendes Group conglomerates. No core exists from the basement/sediment contact, and the well has only $2 \mathrm{~m}$ of basement core from the interval 2907-2909 $\mathrm{m}$. No cores were cut from the Rotliegendes Group (Fig. 5C). The lower $80 \mathrm{~cm}$ of the core consist of a medium-grained, equigranular, granodiorite which is succeeded by $1.20 \mathrm{~m}$ of metamorphosed, foliated sedimentary rock consisting of alternating layers of fine and very fine mineral grains (Figs. 5C, 7; Tables 1, 2). No dissolution or fragmentation of the rock can be seen either in hand specimen or with SEM and XRD analyses (Table 1). Point counting revealed that the granodiorite comprises plagioclase, quartz, subordinate K-feldspar and mica (biotite > muscovite) (Table 2). Plagioclase $\left(\mathrm{Ab}_{100-70}\right)$ is heavily affected by sericitisation which gives it a cloudy appearance, but no other alteration seems to have affected the plagioclase. Under the optical microscope, the biotite does not exhibit altered morphologies, but chloritisation has taken place (Fig. 11D). Pyrite and apatite were associated with the chloritisation. Dissolution of biotite appears to have taken place at the fringes of the mineral, where minor cavities were filled with clays of chloritic composition together with pyrite and rutile. The presence of chlorite within the clay fraction is confirmed by XRD along with fine-grained mica/illite. The amount of total clay in the sample is low but difficult to estimate since chlorite appears both as sand-sized and clay-sized particles. The fine-grained mica/illite fraction probably represents the sericite.

The fine grains of the metamorphosed rock make mineral estimation by optical microscope complicated, but in bulk XRD analysis the composition appears as quartz, plagioclase, biotite, chlorite and traces of illite/mica (Table 1).

\section{6/1-12 (Electronic Supplement 6)}

16/1-12 was drilled in the southwestern part of the Utsira High, just south of the Edvard Grieg field (Fig. 2). Below chalks and marls of the Cretaceous Shetland and Cromer Knoll groups, a thin conglomerate $(20 \mathrm{~cm})$ of the Early Cretaceous Åsgard Formation rests on fractured and partly weathered basement (Fig. 5C). Oil shows have been reported both from the conglomerate and in the fractured and weathered basement (www.npd.no).

A continuous core was recovered spanning the lower part of the Shetland Group, the Cromer Knoll Group and the upper $23 \mathrm{~m}$ of basement (Fig. 5C). Basement is made up of fine-grained inequigranular granodiorite with medium-grained plagioclase pheno- crysts (Fig. 7; Table 2). The primary minerals include quartz, mantled K-feldspar, plagioclase and biotite, with accessory muscovite, zircon and secondary chlorite, finegrained mica (sericite), rutile, ilmenite and hematite (Tables 1,2). The cored section is characterised by crossing fracture patterns, with a slight increase towards the top. Fractures are observed to vary between being open, healed or filled by clay material. Decomposition of the rock is restricted to open discontinuities, which often display rough surfaces where the rock appears friable (W3). In addition, signs of alteration at the macroscopic scale include discolouration of the rock and the scattered occurrence of a vuggy porosity created by dissolution of primary minerals. Fine-grained material (clay) is only observed on fracture surfaces.

Under the optical microscope, pervasive alteration is evident: plagioclase $\left(\mathrm{Ab}_{50-70}\right)$ crystals are affected by severe dissolution, creating intragranular microporosity. Under the optical microscope, plagioclase has been found to be zoned and the zonation has been identified by SEM-EDS to represent differences in the $\mathrm{An} / \mathrm{Ab}$ ratio. This zoning has also affected the dissolution of the grain where the An-rich areas are more prone to alteration while the Ab-rich areas are less affected (Fig. 11C). Dissolution of plagioclase is characterised by vugs that are either open or occupied by precipitated chlorite and kaolinite.

The microcline appears well preserved. However, plagioclase inclusions within the microcline host show signs of alteration. Biotite is the other mineral phase that has been altered. The first signs of alteration seen with the optical microscope are a sinuous development and widening of crystal wafers (001 plane). There is a colour change from brown to a pale green, and ultimately dissolution pores are developed, typically from the centre of the crystal and outwards. SEM-EDS analysis of the same grains illustrates that the colour change is associated with the change from a biotite composition to a more chloritic composition, by the leaching of $\mathrm{K}^{+}$. The chloritisation process is represented by the growth of chlorite along the 001 planes as well as replacement of the biotite mineral in dissolution pores. Ti-oxides (rutile and ilmenite) are typically associated with this process. Secondary orthoclase, distinguished by its anhedral-subanhedral crystal shape, is observed to grow inside the biotite and is also precipitated in cracks through dissolved biotite or plagioclase.

At micro-scale, an increased trend of alteration can be observed from the lower part of the core to the upper part, which is not obvious at the macro-scale. In the lower parts, plagioclase crystals are partially altered, but features such as polysynthetic twinning are still vaguely visible. In the upper part of the core, the plagioclase carries no distinctive features. In addition to dissolution pores, porosity is also created by open microfractures.

Clay minerals are observed with the optical microscope 


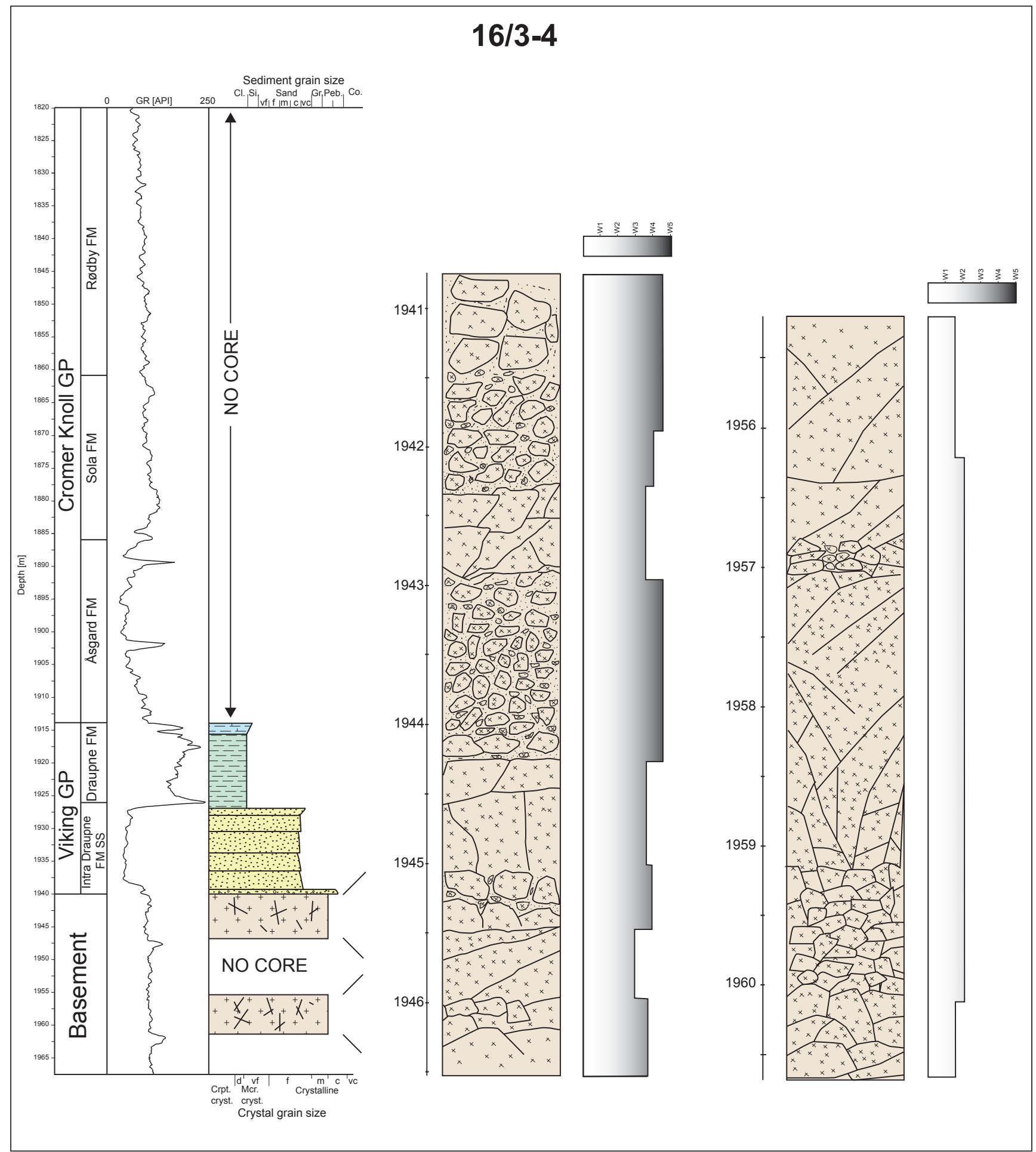

Figure 12. Sedimentary log and sketch from well 16/3-4 showing the degree of weathering (W1-W5) of a medium-grained monzogranite.

and identified as chlorite and kaolinite in SEM-EDS and XRD analyses, though only small traces are present $(<1 \%)$ (Table 1).

Top basement was reached at level $1912.20 \mathrm{~m}$, and succeeded by a $20 \mathrm{~cm}$-thick polymict conglomerate consisting of well-rounded rock clasts (up to $5 \mathrm{~cm}$ ) in a carbonate-cemented, upwards-fining sand matrix. The upper $5 \mathrm{~cm}$ of the conglomerate include shale clasts and shell fragments (belemnites) in a greenish fine-grained matrix. The lithology passes upward into a reddish marl, highly bioturbated with scattered shell debris (Fig. 5C). The boundary between marl and chalk is marked by a thin glauconitic bed at $1902.5 \mathrm{~m}$. The upper $38 \mathrm{~m}$ of the core is comprised of white chalk with thinner beds of red marl intercalated in the lower section, passing into greenish marl stringers in the upper part (Fig. 5C). 


\section{6/4-5 (Electronic Supplement 7)}

Well 16/4-5 was drilled south of the Edvard Grieg field (Fig. 2). It reached basement at $1897.95 \mathrm{~m}$ depth, subjacent to a marl/limestone interval of the Cretaceous Cromer Knoll Group. $26.5 \mathrm{~m}$ of core was cut from basement, in addition to $2 \mathrm{~m}$ of the overlying sediments (Fig. 5C). The basement/sediment contact is marked by a 5 $\mathrm{cm}$-thick layer of white chalk which abruptly changes to a red-coloured, shell-rich and bioturbated marl. Another thin layer $(2 \mathrm{~cm})$ of white chalk is present at $1896.50 \mathrm{~m}$ while the upper part of the core is characterised by red marl comparable to the one below (Fig. 5C).

The basement composition is dominated by plagioclase and quartz, with subordinate K-feldspar, biotite, and traces of muscovite with associated carbonates and titanium- and iron oxides (Tables 1,2). The rock plots in the granodioritic area in the QAP diagram, but intrusions of more syenitic/granitic and pegmatitic composition are observed throughout the cored section (Fig. 7). The entire basement core is characterised by a high degree of fracturing. The fractures are partly open, commonly lined with carbonate cement, or completely carbonate cemented. In open fractures a darker material was sometimes observed, interpreted to be organic matter (tar/ oil). Under the optical microscope, microfractures can be identified. They are for the most part clogged by iron oxides (hematite), Mg-rich calcite or kaolinite.

No pervasive alteration of the rock has been identified in hand specimens, but minor disintegration has occurred along fracture planes. A sample taken in close vicinity to one of these fractures displays the presence of kaolinite and fine-grained mica/illite in the XRD clay fraction analysis. In SEM, biotite is observed to widen along the 001 planes, accommodating kaolinite and Mg-rich calcite and dolomite. Areas of major dissolution in plagioclase and biotite are not common but when present, pore space is occupied by kaolinite, carbonates, and small pockets of a smectitic clay mineral, often associated with rutile.

\section{6/5-1 (Electronic Supplement 8)}

16/5-1 is from the south-central part of the Utsira High (Fig. 2). Thirteen metres of basement core have been cut from the 1929-1942 m interval, just below the sediment/ basement contact at depth $1925 \mathrm{~m}$. The overlying sediments have been reported to belong to the Cretaceous Åsgard Formation (www.npd.no), but no core exists (Fig. $5 \mathrm{C})$.

The crystalline basement exhibits a monzogranitic/ granodioritic composition with equigranular and medium-grained textures (Fig. 7; Table 2). Plagioclase and quartz are the dominating constituents, with subordinate $\mathrm{K}$-feldspar (Table 2). Biotite is the most common of the phyllosilicates (Fig. 11F), but muscovite/sericite is also present as well as traces of chlorite. Certain intervals contain a high amount of carbonates (calcite $>$ dolomite).

The entire cored interval is distinguished by a high fracture frequency varying from open to being filled by calcite cement (Fig. 8D). In certain intervals the rock is fragmented, and this is where alteration is most prominent; the first evidence being the colour change from bright red to pale red corresponding to $\mathrm{W} 2$ in the alteration scale. In the most altered intervals, alteration reaches up to W3. XRD bulk scans from this level reveal high amounts of calcite $(\sim 45 \%)$. The clay fraction is dominated by smectitic clays, but fine-grained mica/illite and chlorite are also present, while kaolinite constitutes the rest with a minor addition of a mixed-layered illite/ smectite phase (Table 1). By SEM-EDS analysis, smectite has been identified both along widened 001 planes in biotite and in dissolution cavities that are commonly associated with high Mg-calcite and dolomite. Most alteration appears to have taken place within biotite. Plagioclase, except for sericitisation, is less affected. Unaltered plagioclase shows original zoning, represented by a changing $\mathrm{Ab} / \mathrm{An}$ ratio. In less altered samples the total clay amount is lower, but the internal portions within the clay fraction are the same as in the more altered samples, with smectite being the main secondary phase.

There seems to be no obvious trend of increasing alteration upwards in the core, suggesting that the alteration processes are mostly controlled by fractures. The more clay-rich samples show a decrease in plagioclase and biotite, but no decrease is observed in the quartz and K-feldspar content (Fig. 10).

\section{6/3-2 (Electronic Supplement 9)}

Located in the east-central part of the Utsira High, the well penetrates coarse-grained, glauconitic and partly calcite-cemented Upper Jurassic sandstones sitting on basement at $2015 \mathrm{~m}$ depth (Fig. 2). A $1.5 \mathrm{~m}$ basement core was recovered from the 2017.5-2019 m interval, and additionally around $2.5 \mathrm{~m}$ of the sandstone was cored between 1998 and $2000.6 \mathrm{~m}$ (Fig. 5C). Classification of the basement, based on modal analysis, shows it to be a coarse-grained, equigranular monzogranite (Figs. 7, 13B; Table 2).

Basement appears fresh in core view, with only minor fracturing (possibly due to core handling) and no visible alteration. The granite contains quartz, plagioclase and subordinate $\mathrm{K}$-feldspar. The granite is rich in mica, with almost twice as much biotite than muscovite (Table 2).

Under the optical microscope, plagioclase $\left(\mathrm{An}_{50-70}\right)$ appears slightly hazy and sericitised, but polysynthetic twinning is still well defined. Dissolution of plagioclase was not observed under the microscope or in SEM (Fig. $11 \mathrm{~A})$. Biotite is the mineral phase showing most signs of 
alteration. Chloritisation was indicated under the optical microscope and confirmed by SEM-EDS analysis. The centre of the mineral is commonly intact, but it is splayed at the fringes and chloritisation and dissolution has occurred, associated with the precipitation of rutile and apatite.

Traces of fine-grained mica/illite, kaolinite, chlorite and a smectitic clay mineral have been confirmed from the XRD clay fraction analysis (Table 1 ).

\section{6/6-1 (Electronic Supplement 10)}

Well $16 / 6-1$ is the easternmost well from the southern Utsira High included in this study (Fig. 2). It is located on the southern tip of a large horst structure trending $\mathrm{N}-\mathrm{S}$ (www.npd.no). Top basement is reached at $2055 \mathrm{~m}$. The basal sedimentary interval (2055-2051 m) has not been attributed to any lithostratigraphic unit (Undefined Group), but is succeeded by $32 \mathrm{~m}$ of the Upper Jurassic Draupne Formation (Fig. 5C). Only $4.5 \mathrm{~m}$ of core were cut, spanning the basement interval 2056.5-2061 m. The crystalline bedrock in this well stands out by revealing the only volcanic rock encountered in the study. It has a microcrystalline to very fine texture with phenocrysts of plagioclase and quartz of about $1-2 \mathrm{~mm}$. No mineral estimation has been possible by optical microscopy, but the XRD composition reveals plagioclase and quartz in almost equal amounts with only minor K-feldspar. This classifies the rock at the border between dacite and quartz andesite in a QPA classification scale for volcanic rocks (Fig. 7). In addition, chlorite and minor amounts of pyrite are present.

There are no signs of alteration of the rock in hand specimen, only minor fracturing at the top of the core. Under the microscope it is seen that plagioclase phenocrysts $\left(\mathrm{Ab}_{90-100}\right)$ are highly affected by sericitisation which dampens the polysynthetic twinning, but no dissolution appears to have taken place. Chlorite displays slightly sinuous 001 planes. Dissolution pits are observed in close proximity to the chlorite grains (Table 1).

\section{6/1-4 (Electronic Supplement 11)}

The well was drilled in the southwestern part of the Utsira High (Fig. 2). The lowest sedimentary unit is the Lower Cretaceous Sola Formation, and immediately below, top basement was reached at $1864 \mathrm{~m}$. A $6 \mathrm{~m}$-long core was recovered from the interval between 1936 and $1942 \mathrm{~m}$ (Fig. 5D). The cored interval consists of a medium-grained, equigranular gabbroic rock with lighter, more syenitic intrusions (Figs. 7, 13C; \& Table 2). The basement is fractured and highly brecciated. Fractures are observed with both slickensides and friable rock surfaces, while others are healed by calcite (Table 1).
Primary minerals were found to be plagioclase (An $>50 \%$ ), amphibole (hornblende), K-feldspar and biotite with accessory chlorite, muscovite/sericite, dolomite, titanite and epidote (Tables 1, 2). In a QAP diagram, the rock plots as a monzogabbro, and more specifically as a hornblende gabbro in a $\mathrm{Plg}-\mathrm{Px}-\mathrm{Hbl}$ diagram (Figs. 7, 13C).

Under the optical microscope, feldspars seem heavily affected by sericitisation, causing a hazy appearance and obscured twinning. In the SEM-EDS, dolomite, epidote, apatite and secondary K-feldspar are observed as inclusions and veins in plagioclase. Other signs of alteration of hornblende and plagioclase are replacement by clay minerals along edges and in scattered patches inside the mineral. Biotite is partly replaced by chlorite associated with sphene and apatite, and clay minerals are observed along the edges of widened crystal laths. Smectitic clays were identified from XRD clay samples, accounting for around half of the total clay, while equal amounts of fine-grained mica/illite and chlorite make up the rest (Table 1).

\section{6/2-1 (Electronic Supplement 12)}

The well was drilled in the west-central part of the Utsira High (Fig. 2). The well report mentions the observation of dead oil/tar in fractured basement rocks (www.npd. no). Top basement is reached at $1873 \mathrm{~m}$, below the Mid Aptian-Early Albian Sola Formation (Fig. 3). Altogether, around $2.5 \mathrm{~m}$ of core was cut from the $1879-1880 \mathrm{~m}$ and 1882-1883.6 m intervals in basement, and thus the basement/sediment contact itself has not been observed (Fig. 5D). Modal analysis shows the rock as a fine-grained, equigranular granodiorite (Figs. 7, 13D; Table 2). The core appears highly fractured, with green-coloured slickensided surfaces, but no other signs of alteration are observed along or between fractures.

The basement composition has been determined by modal analysis with main minerals quartz, K-feldspar and plagioclase and with lesser amounts of chlorite, biotite and muscovite (Table 1). Small amounts of calcite and dolomite are revealed in the XRD analysis. In thin-section, microfractures are observed crossing grain contacts and passing through grains. They are partly filled with chlorite and iron oxides. Alteration of plagioclase results in a hazy appearance and dampening of the polysynthetic twinning. The plagioclase grains are moderately sericitised and also associated with a larger pleochroic phase. Biotite is altered to chlorite associated with an opaque phase (pyrite).

The clay fraction is represented by very small amounts of chlorite and fine-grained mica/illite as determined by XRD analysis (Table 1). 

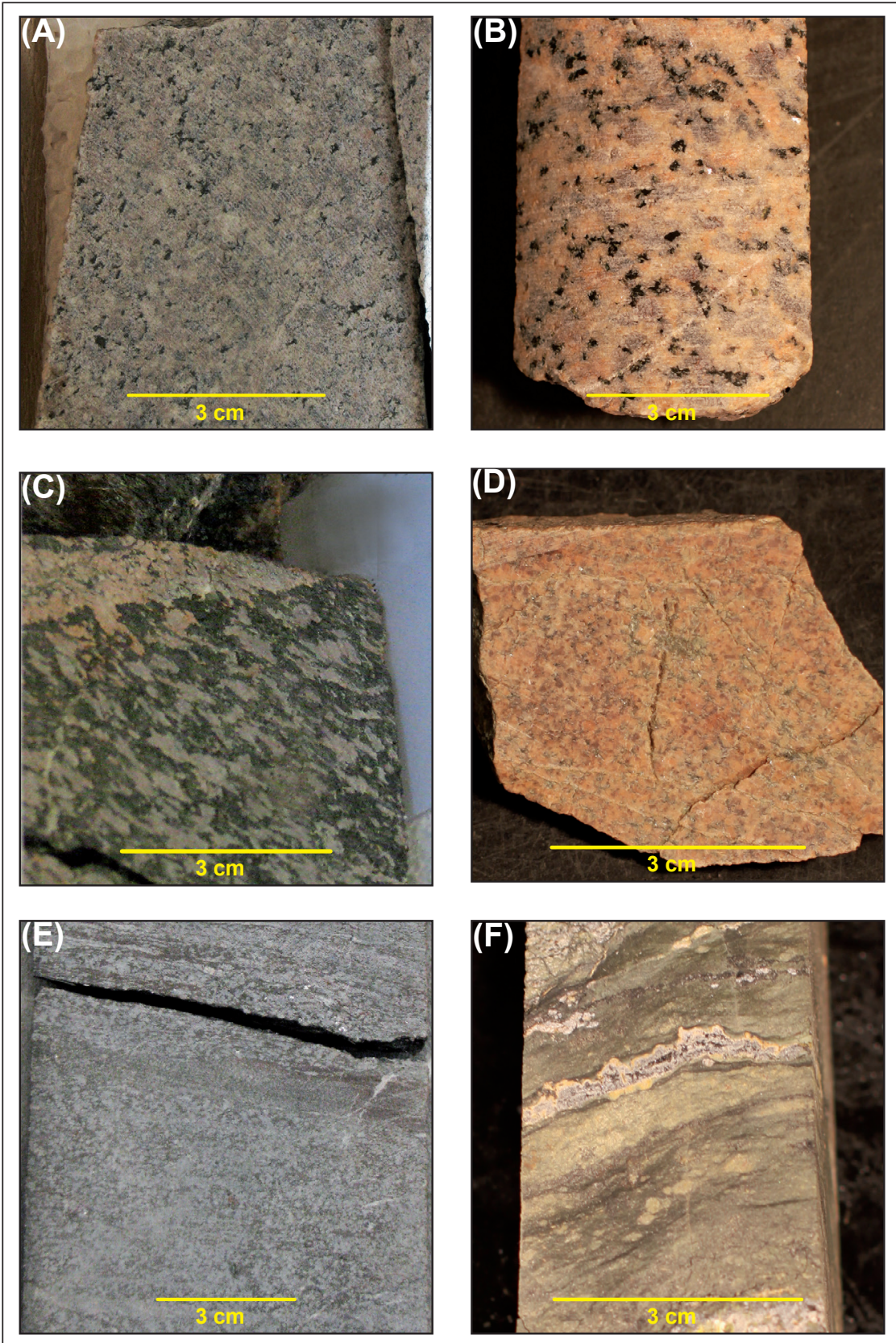

Figure 13. Selection of core photos displaying the different types of basement rock observed on the Utsira High. (A) 16/3-4 (medium-grained monzogranite). (B) 16/3-2 (coarse-grained monzogranite). (C) 16/1-4 (medium-grained hornblende gabbro). (D) 16/2-1 (fine-grained granodiorite). (E) 25/11-17 (phyllite). (F) 25/7-1S (metasandstone).

\section{5/11-17 (Electronic Supplement 13)}

This well was drilled in the central part of the Utsira High, south of the Balder/Grane area (www.npd.no) (Fig. 2). Ten metres of weathered rock have been reported to overlie basement in the $2233-2243 \mathrm{~m}$ interval, which is succeeded by almost $90 \mathrm{~m}$ of Permian Zechstein Group deposits and about $150 \mathrm{~m}$ of Triassic sediments interpreted to belong to the Statfjord Formation (www.npd. no) (Fig. 5D). No core was cut in the possible weathered section, but $\sim 8 \mathrm{~m}$ exist from basement in the interval between 2248 and $2255.9 \mathrm{~m}$ (Fig. 5D).
The basement consists of foliated metamorphic rocks (Fig. 13E). Crystal size varies between microcrystalline and very fine-grained, the exceptions being elongated micas of up to $0.5 \mathrm{~mm}$. The rock composition is dominated by quartz and micas, with minor K-feldspars and only traces of plagioclase, as identified by XRD and the optical microscope (Fig. 14D; Table 1). The presence of calcite is closely related to fractures, which explains the difference in amount from $<1 \%$ to $>20 \%$ over an interval of $6 \mathrm{~m}$. Micas are present as muscovite, biotite and chlorite, with muscovite being most prominent. The total mica content is high, making up about one-third of the 
rock. Under the optical microscope, elongated grains show preferred orientation. The foliation, grain size and high mica content suggest that this rock should be classified as a phyllite (Fig. 13E).

In core, the rock appears moderately fractured with no obvious zones of alteration. Vertical/inclined fractures are commonly healed by calcite and subsequently cut by horizontal fractures which are either open or quartzcemented. Quartz is also present as phenocrysts within the foliated schist.

Chloritisation of biotite is observed under the optical microscope, but overall, biotite displays unaltered morphologies. In more porous areas clay minerals are possibly present. XRD from the clay fraction has revealed chlorite to be the dominating clay-sized mineral, but a mixed-layered expandable phase and kaolinite are also identified (Table 1).

\section{5/10-2R (Electronic Supplement 14)}

Well 25/10-2 was drilled on the down-faulted western flank of the Balder Field on the northwestern side of the Utsira High (www.npd.no) (Fig. 2). Basement was reached at level $3152 \mathrm{~m}$, below a thick package of conglomerates belonging to the Rotliegendes Group. Only $0.5 \mathrm{~m}$ of basement core exists, from the interval 3177.25$3177.55 \mathrm{~m}$, while a total of $49 \mathrm{~m}$ of core were recovered from the overlying Rotliegendes and Zechstein groups (Fig. 5D). The basement is classified as an inequigranular (fine-grained/coarse-grained) quartz-monzonite consisting of mantled K-feldspar, plagioclase and minor quartz (Fig. 7). In addition, minor amounts (up to 10\%) of calcite and hematite are present. Mineral estimation was undertaken by XRD due to the small grain size. The cored section consists of broken pieces of angular rock fragments up to a size of a few centimetres, making it complicated to determine the relative position of individual clasts. Slickensides and calcitic veins are observed in a few of the rock fragments. Alteration of the rock is not prominent in hand specimen.

Under the optical microscope the K-feldspars are characteristically perthitic (Fig. 9F). Microfractures are occupied by calcite and hematite, the presence of which is confirmed by SEM-EDS analysis (Fig. 9F). Dissolution has taken place in plagioclase $\left(\mathrm{Ab}_{70-90}\right)$ resulting in dissolution cavities later filled by secondary clay minerals. The identification of clays has been undertaken by both SEM-EDS and XRD ( $<2 \mu \mathrm{m}$ fraction) analysis which both confirm the presence of kaolinite and fine-grained mica/illite (Table 1). Hematite is also observed within the very same cavities.

\section{5/11-1 (Electronic Supplement 15)}

Well 25/11-1 has been branded the first oil discovery on the Norwegian Continental Shelf, although the Paleocene reservoir rocks were found to be too thin to justify further investigation (www.npd.no). The well was drilled on the north-central part of the Utsira High (Fig. 2). Basement is reached at $2391 \mathrm{~m}$, below an almost 300 m-thick interval of sediments belonging to the Middle to Upper Triassic Skagerrak Formation (www.npd.no) (Fig. 5D). The sediment/basement contact has not been cored, but an $18 \mathrm{~m}$ core from the sedimentary unit was cut from the 2345-2363 $\mathrm{m}$ interval. The lower and upper parts of the sediment core consist of an upwards-fining and bedded sandstone, which is separated by a $3 \mathrm{~m}$-thick interval (2346-2349 m) of clay/silt and interbedded marl.

Two basement cores have been collected, one from the 2391-2395 m interval and one from 2448-2458 m, representing two different lithologies. The lower interval (2448-2458 m) shows a fractured, metamorphic rock. XRD analysis shows the rock to consist of $>90 \%$ calcite, with only a minor contribution from quartz, plagioclase, K-feldspar and illite/mica, and consequently it has been classified as a marble (Fig. 14; \& Table 1). Fractures are either open, often with slickensides, or calcite cemented. At certain levels, e.g., $2453 \mathrm{~m}$, brecciation is evident, manifested by cemented marble clasts. The upper basement core (2391-2395 $\mathrm{m}$ ) is a fine-grained, equigranular gneissic schist consisting of polycrystalline quartz, chlorite, muscovite and biotite (Fig. 14; Table 1).

In core, the rock appears as broken clasts (Fig. 5D). Close inspection of the individual pieces demonstrates alteration to the degree of W3 on the classification scale. The fragmented state of the core makes it difficult to observe whether there is an upwards-increasing trend in the alteration. Under the optical microscope pores are observed to be either open or filled by illite or chlorite. From XRD clay analysis, chlorite and fine-grained mica/ illite are the only clay minerals confirmed (Table 1).

\section{5/7-1S (Electronic Supplement 16)}

The well is located on the northwestern flank of the Utsira High (Fig. 2). Drilled in a fault zone, basement was reached at $3551 \mathrm{~m}$, below the Cretaceous Rødby Formation (www.npd.no). One core was cut in the 3547-3554.8 $\mathrm{m}$ interval spanning the sediment/basement contact, and another from the 3589-3591.5 $\mathrm{m}$ interval (Fig. 5D).

The basement consists of brecciated, metamorphic sandstone (Fig. 13F). The upper part is made up of fine-grained quartz grains and micas (muscovite and chlorite). In addition, iron sulphides are abundant both as pyrite and marcasite (Fig. 14A). In the lower part quartz still dominates the metasandstone, making up over $90 \%$ of the total rock components. Mica (muscovite $>>$ chlorite) and minor amounts of K-feldspar are also present (Table 1). 


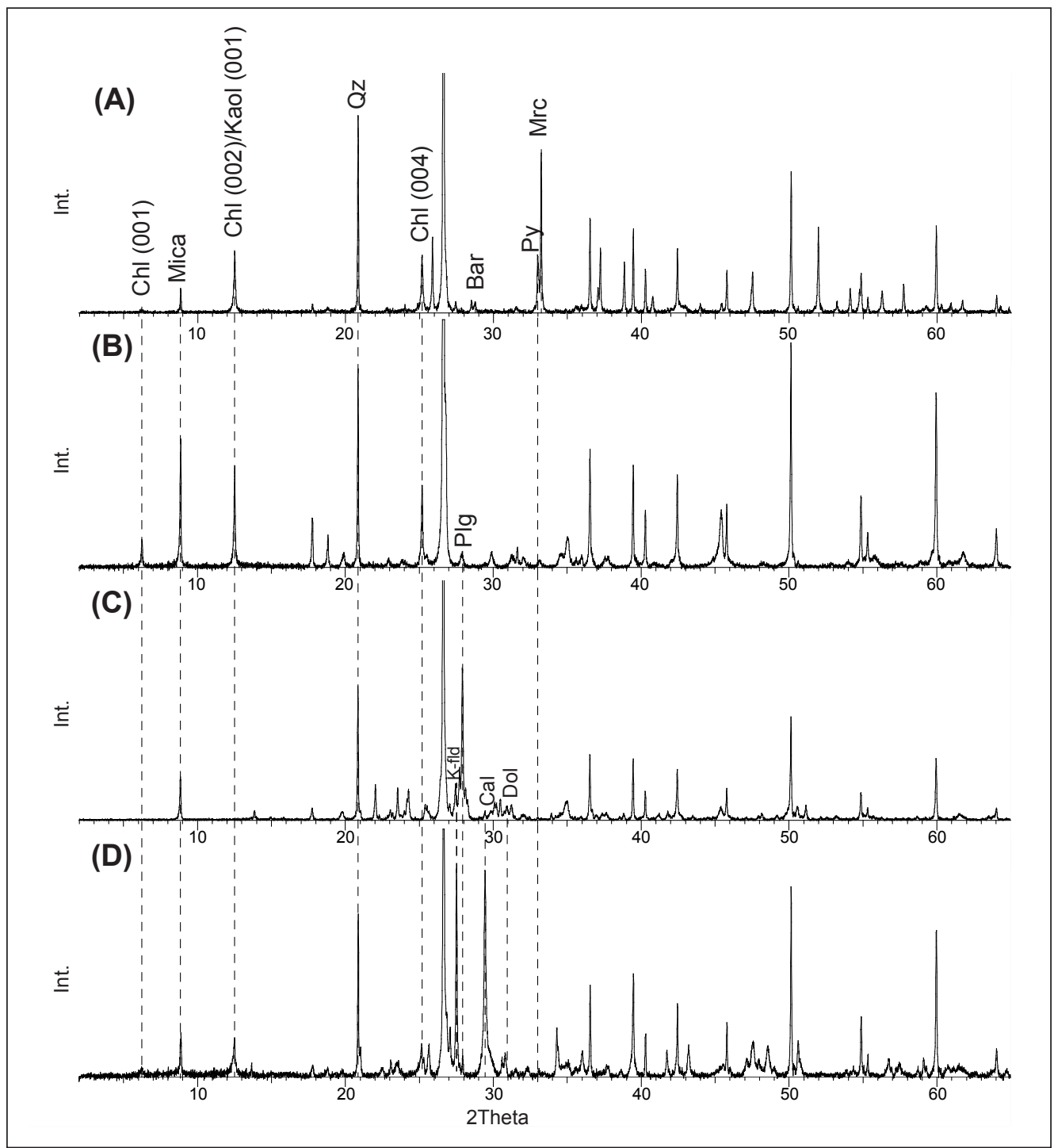

Figure 14. X-ray diffractograms showing the bulk mineral composition of the rocks where standard classification in QAP-diagram is not possible (25/7-1S, 25/11-1, 16/3-4A and 25/11-17). Dashed vertical lines indicate the identification of the main mineral phases. Abbreviations: Int. - count intensity, Chl - chlorite, Kaol - kaolinite, Qz - quartz, Bar - barite, Py - pyrite, Mrc - marcasite, Plg - plagioclase, K-fld - K-feldspar, Cal - calcite, Dol - dolomite. (A) 25/7-1S (metamorphic), (B) 25/11-1 (metamorphic), (C) 16/3-4A (altered granite(?)) and (D) 25/11-17 (metamorphic).

In macroscopic view, the basement rock appears as a breccia with the fragments cemented by a greenishyellow matrix and iron sulphides. XRD clay fraction analysis shows fine-grained mica/illite and small amounts of chlorite as the only clay minerals present (Table 1). In addition, silt/clay-sized quartz and possibly feldspars are seen under the optical microscope.

\section{Discussion}

The eighteen basement cores presented from the Utsira High show great variability, both in terms of original composition and post-crystallisation evolution. The main alteration parameters examined are the physical appearance of the rock, that is the degree of alteration on a scale of W1 to W5, and the presence of secondary minerals as determined by optical microscope, SEM-EDS and XRD analyses. The term alteration is used in its broadest sense and can be thought of as all the processes affecting the composition and texture of the rock after solidification. The crystalline bedrock on the Utsira High has had an eventful past including its Caledonian origin and a tectonically active period from Permian to Early Cretaceous. During this time, the high was subaerially exposed for long periods followed by periods of quiescence and associated subsidence. Hence, the end product as seen today may have resulted from several different processes or combinations of these processes, i.e., post-magmatic alteration, metasomatism, subaerial weathering and/or diagenesis.

The southern Viking Graben area is characterised by numerous faults. Chester et al. (1993) subdivided a fault zone into the fault core, which is a narrow zone close 
to the fault plane characterised by ultracataclasites, and a wider zone of damaged rock characterised by localised zones of cataclasites, fractures, subsidiary faults and abundant microscopic fractures. A common denominator in the altered rocks at the Utsira High is the presence of joints and fractures, but their nature is variable (Table 2). Brecciation (following the definition by Woodcock \& Mort, 2008) observed in well 25/7-1S (cohesive) and 25/10-2 (incohesive) fits well with their position within known fault zones (www.npd.no) (Fig. 2). The presence of smoothed surfaces indicative of slickensides, observed in wells $16 / 2-1,25 / 11-1$ and $25 / 10-2$, is also taken as evidence of fault movement (Fig. 2).

In most of the wells included in this study the fracture intensity has been classified as medium or high (Table 1). During water-rock interactions (e.g., during subaerial weathering), fractures will enhance the permeability (Woodcock \& Mort, 2008) and increase the surface area reacting with fluids (Pacheco \& Alencoão, 2006), and they thus contribute an important parameter in rock alteration. In wells $16 / 3-2,16 / 6-1$ and $25 / 7-1 S$, the low fracture intensity coincides with a low degree of alteration. In cores where fractures are present, they are visible both in hand specimen and as micro fractures observed under the microscope. The first signs of alteration can generally be observed along fractures (Fig. 8D; Table 1). When disintegration is accompanied by mineralisation, fluid-rock interactions have occurred.

The inclusion of a clay-sized micaceous mineral, namely sericite, in plagioclase crystals has been observed in all rocks of plutonic origin except at 16/2-4 (Fig. 9B). The widespread appearance of sericite suggests that the process of sericitisation occurred during the final stages of crystallisation (deuteric alteration) rather than during a more localised hydrothermal alteration (Speer, 1984; Que \& Allen, 1996). The sericitisation process is characterised by the replacement of plagioclase by sericite and the replacement of $\mathrm{Ca}^{2+}$ by $\mathrm{Na}^{+}$, and is thus often concentrated in the more anorthitic zones of the plagioclase crystal (Que \& Allen, 1996). The process can be coupled with the transformation of biotite to chlorite (Speer, 1984; Eggleton \& Banfield, 1985; Que \& Allen, 1996). The chloritisation corresponds to the alteration of biotite manifested by the change in colour from brown to green along the 001 plane as observed under the optical microscope and the concurrent depletion of $\mathrm{K}^{+}$as discovered by the SEM-EDS analysis (e.g., Fig. 9E). The presence of barite, as detected by XRD in well $25 / 7-1 S$, is a common contamination in XRD analysis from drilling cores, most likely introduced by the drilling fluids (Dypvik, 1981).

Secondary calcite and dolomite are observed in several cores (Electronic Supplement 17), and may have multiple origins. During the sericitisation of anorthite, $\mathrm{Ca}$ is released and can be precipitated as fine calcite inclusions (Wilamowski, 2002). However, carbonates are also a common feature in weathering profiles where they form early in the diagenesis by the reaction with groundwater (Nesbitt \& Young, 1989)

The clay mineral associations identified by XRD and SEM-EDS analysis (Table 2) are evidence of alteration of the protolith, but may conceivably be the result of multiple processes. Their origin is either by direct precipitation from solution (neoformation), transported with little or no modification (inheritance) or by transformation of one clay mineral to another (transformation) (Galán, 2006). Clay minerals form in different geological environments and the following origins will be considered in this study: subaerial weathering, diagenesis, low-grade metamorphism and hydrothermal alteration (Galán \& Ferrell, 2013).

When assessing the different mineralogical and textural features identified, the wells have been grouped according to the age of the basal sedimentary unit. The age of the sedimentary unit above basement is thought to represent the youngest possible age of subaerial weathering.

\section{Pre-Permian}

Three basement cores with superjacent Permian sediments have been evaluated in this study: 16/4-1, 25/102R and 25/11-17 (Fig. 2): the first reveals a metasandstone overlying a medium-grained granodiorite, while the other two show a fine-grained quartz-monzonite and phyllite, respectively (Table 1).

Well $25 / 10-2 \mathrm{R}$ is located on the western flank of a large half-graben structure which is filled with pre-Permian(?) sandstones and shales, fluvial Rotliegendes conglomerates and Zechstein evaporites and carbonates (Fig. 2) (Brekke et al., 2001). The sediment may locally have been sourced from exposed bedrock on the flanks of the structure.

The identification of precipitated hematite and kaolinite, observed in dissolution cavities in plagioclase $\left(\mathrm{Ab}_{70-90}\right)$, could indicate subaerial weathering. Nahon (1991) showed how the two phases are formed in laterites under humid and well drained conditions, which is not in accordance with the Permian climate in the North Sea region (Glennie \& Underhill, 1998). According to Weaver (1989), diagenetic kaolinite, illite and hematite are common in the Lower Permian Rotliegendes in the North Sea. The presence of intra- and intergranular calcitic veins can originate from percolating groundwater (Clauer et al., 1989). Considering the fragmented state of the quartz-monzonite it is not unlikely that the rock behaved similarly to the overlying sediment during burial, where calcite, illite and hematite formed during shallow burial. The formation of kaolinite at the expense of $\mathrm{K}$-feldspars represents the next diagenetic stage.

The fact that the basement interval in core $25 / 10-2 \mathrm{R}$ is confined to about $30 \mathrm{~cm}$, collected 
$25 \mathrm{~m}$ below top basement, makes it difficult to identify the processes responsible for alteration. The observed slickensides could suggest that the fragmentation of the rock represents fault brecciation. In the other two wells (16/4-1 and 25/11-17), no signs of subaerial weathering have been observed or can be expected due to the compositional domination of resistant minerals such as quartz and muscovite (Goldich, 1938). The presence of chlorite and fine-grained mica/illite is attributed to the sericitisation and associated chloritsation of biotite during deuteric alteration.

\section{Pre-Middle Triassic}

Only one of the studied basement cores is overlain by Triassic sediments, well 25/11-1, where alluvial sandstones of the Skagerrak Formation overlie a gneissic schist. The dominant minerals of the schist are quartz with additional muscovite (Table 2), both resistant minerals (Goldich, 1938). Therefore, the development of a weathering profile in this type of lithology is unlikely. Furthermore, the warm and dry climate in Mid Triassic time (Lidmar-Bergström, 1993) would not normally favour extensive chemical weathering. The brecciated nature of the core can be attributed to fault movements.

\section{Pre-Upper Jurassic}

Five basement cores (16/3-2, 16/3-4, 16/3-4A, 16/3-6 and 16/6-1) are located below Upper Jurassic sandstones of the Draupne Formation. They are exclusively located on the Avaldsnes high, east of the Augvald graben (Fig. 2).

The tropical and humid climate prevailing from the Late Triassic and through certain periods of the Jurassic, favoured deep chemical weathering of basement rocks in Fennoscandia (Abbink et al., 2001; Lidmar-Bergström et al., 2009). Evidence of deep weathering during the Jurassic/Early Cretaceous has been identified in southern Sweden (e.g., Lidmar-Bergström 1982, 1995, 1996; Migón \& Lidmar-Bergström, 2001; Ahlberg et al., 2003). Possible time-equivalent remnants in southern Norway have been suggested by Olesen et al. (2006) and Riis (1996), and these might extend westward into the North Sea region (Roaldset et al., 1993). Fredin et al. (2014) performed KAr dating of authigenic illite from the altered basement cores from wells 16/3-4 and 16/1-15. The results indicate a Late Triassic age, which led the authors to conclude that deep weathering observed offshore is time equivalent to that reported from onshore localities. The climatic conditions during the Carboniferous would also have been favourable for deep chemical weathering (Weaver, 1989; Brekke et al., 2001). It is possible that even the Late Triassic/Jurassic weathering imprint may have been preceded by a Carboniferous weathering phase. However, apatite fission-track analysis by Ksienzyk et al. (2013) suggest that the basement at the southern Utsira High was not exposed until the Triassic. Furthermore, boreholes from the nearby Augvald graben (informal name) have not yet revealed sediments of Carboniferous age. Therefore, a Carboniferous weathering phase is deemed possible, but somewhat speculative at the moment.

Well 16/3-4 displays highly altered granodioritic rocks (Fig. 8C). There is clearly an upwards-increasing degree of disintegration of the rock, going from $\mathrm{W} 1 / 2$ at the core base and up to totally decomposed rock (W5) at the top (Fig. 12). The clay mineralogical analysis has shown the predominance of kaolinite, also increasing towards the top of the core (Fig. 12; Table 1). Both observations suggest a top-down alteration agent which is in accordance with subaerial weathering. In the SEM, kaolinite is observed within and around dissolved plagioclase and within splayed biotite. Plagioclase and biotite are transformed through intermediate phases to kaolinite in the weathering environment (Tardy et al., 1973). Smectite, representing one of these intermediate phases, has been identified in the lower part of the profile. Fig. 10 shows (plagioclase + biotite) and (quartz + K-feldspar) contents plotted against the clay content. In the (plagioclase + biotite) vs. clay plot (Fig. 10A) there is a clear correlation between decreasing (plagioclase + biotite) values and increasing clay content. For the (quartz $+\mathrm{K}$-feldspar) vs. clay (Fig. 10B) there is no such relationship, indicating that the main sources for secondary clays are the plagioclase and biotite. This accords well with the Goldich weathering series stating that plagioclase and biotite weather more readily than K-feldspar and quartz (Goldich, 1938).

Well 16/3-6 is located two kilometres north of 16/3-4, and here the alteration is less pronounced (Fig. 2). Alteration is mainly located along fractures. The clay mineral association, with a preponderance of smectite and subordinant fine-grained mica/illite, kaolinite, chlorite and illite-chlorite, is similar to that observed in the lower part of 16/3-4. The cored section of $16 / 3-6$ is thus believed to represent the lower part of an ancient weathering profile, where the upper part of the weathering profile has partially been removed and remnants are preserved mainly along fracture zones. This is comparable to the interpretation by Olesen et al. (2006) and Lidmar-Bergström (1995) from preserved Triassic/Jurassic weathering profiles in southern Norway and Sweden.

On the eastern side of the Avaldsnes high (informal name), a basement core has been recovered from well 16/3-2 (Fig. 2). At first glance the rock appeared unaltered, but the SEM and XRD analysis show minor dissolution of plagioclase with the resulting precipitation of kaolinite. This suggests that a thicker weathering profile could have been present but has later been removed. In well 16/6-1, no remnants of a possible weathering profile have been preserved. This well is reported to have been drilled crestally on a big horst feature (www.npd. no), and this topographic position would have made it vulnerable for erosion. 
Well 16/3-4A was drilled as a sidetrack upflank towards the Avaldsnes high (Fig. 2). The rock is highly altered but Mg-rich illite and fine-grained mica (sericite) are the only resulting clay minerals which have been identified by SEM-EDS and XRD. Considering diagenetic effects, the illitisation of kaolinite is believed to normally occur at a depth of 3-4 km (Mantovani \& Becerro, 2010), although Bjørkum \& Gjelsvik (1988) have reported the process taking place at a much shallower depth in the presence of K-feldspar. A smectitic precursor is also possible. Alternatively, the illite can originate from processes of hydrothermal alteration, which are known to occur in fault zones (Bruhn et al., 1994). In addition, this could also explain the precipitation of carbonates (calcite and dolomite).

\section{Pre-Lower Cretaceous}

The Lower Cretaceous Cromer Knoll Group overlies basement rocks in eight of the wells included in this study (16/1-4, 16/1-12, 16/1-15, 16/1-15A, 16/2-1, 16/2-4, $16 / 4-5$ and 16/5-1). The wells are exclusively located west of the Augvald graben on the Haugaland high (informal names) (Fig. 2). The younger age of the basal sedimentary unit in the west compared to the east may be explained by the higher elevation of basement in this area, and thus transgression and marine sedimentation occurred later. In well $16 / 1-15$, the $47 \mathrm{~m}$ of recovered core display an upwards increase in pervasive alteration that reaches W4/5 on the alteration scale (Figs. 6, 8A), suggesting formation through subaerial weathering. The low clay content indicates that the weathering has taken place in the form of arenisation rather than the argillisation observed in, for example, 16/3-4 (Fig. 8C).

The clay mineralogy suite of fine-grained mica/illite, with chlorite and smectite dominating over kaolinite, suggests that weathering has taken place during dissimilar climatic conditions or in a different topographic setting than the weathering at 16/3-4 (Avaldsnes high) (Tardy et al., 1973; Sequeira Braga et al., 1990). An alternative interpretation has been proposed by Olesen et al. (2013), suggesting erosion of the clay-rich upper portion of the weathering profile, with preservation only of the clay-poor, deeper part of the profile. A similar, but less pronounced, development as in $16 / 1-15$ is observed in 16/5-1, where the alteration is restricted to fractures, with smectite being the dominate clay mineral. In well 16/1-15A (sidetrack to 16/1-15) alteration can only be observed with the help of SEM and $\mathrm{XRD}$, represented by the minor dissolution of plagioclase and biotite and the precipitation of kaolinite. The great differences over relatively short distances, as represented by $16 / 1-15$ and $16 / 1-15 A$, may be further evidence that much of the saprolitic cover was stripped prior to the Early Cretaceous transgression, as suggested by LidmarBergström (1995). In wells 16/1-12 and 16/4-5, the only observed alteration in hand specimen is along fractures where kaolinite has precipitated at the expense of plagioclase and biotite.
Well $16 / 1-4$ stands out as being the only core in the study where gabbroic lithologies were encountered. The recovered core was taken almost $70 \mathrm{~m}$ into the basement, making it impossible to decide whether deep weathering has taken place. Smectitic clays have been identified, which probably originate from the dissolution of hornblende, classified between plagioclase and biotite in the Goldich weathering series (Goldich, 1938). The weathering of mafic rocks has been shown to develop thinner horizons of saprolite than from a more acidic basement. The predominance of secondary products such as smectite and vermiculite are believed to allow for lower hydraulic conductivity and thus increased run-off and through-flow than in saprolites developed from acidic rocks (Buol \& Weed, 1991). In 16/2-1 and 16/2-4, no signs of alteration have been detected, suggesting that either weathering never took place or the profile has been completely eroded (Table 1).

\section{Petroleum geological significance}

Porosity and permeability are developed in the basement rocks on the Utsira High along fractures and by weathering-induced dissolution and fragmentation. Fractures and weathering sites can act together, as in, e.g., wells 16/3-4 and 16/1-15. In those cases, the fracture porosity and the porosity caused by the dissolution of minerals needs to be treated as two separate systems (Nelson, 2001). In other wells, e.g., 16/1-12, weathering plays only a minor role and fractures dominate. In general, fracture porosity is poor but highly interconnected and can contribute much more than the weathering to permeability, and thus act as migration paths for hydrocarbons (Nelson, 2001). However, the storage capacity in fractured basement rocks is low and in order for it to function as a reservoir, an overlying porous saprolite or sediment is required (Wright, 1992). In areas where the saprolite forms extensive blankets, it has been shown to be an excellent aquifer, and potentially a good reservoir also for hydrocarbons (Wright, 1992). At the Utsira High, however, weathering mantles are apparently only preserved locally and large lateral variations are observed over short distances e.g., in 16/1-15 and $16 / 1-15 \mathrm{~A}$. It is therefore assumed that the saprolite, when present, can contribute to the reserves only when covered by a more lateral continuous reservoir rock. Acworth (1987) showed that the permeability of saprolites diminished as the amount of secondary minerals (clay) increased. Hence, the type of clay-rich saprolite observed in 16/3-4 probably has lower reservoir potential than the more clay-poor saprolite observed in 16/1-15.

\section{Conclusions}

Most of the basement rocks from the Utsira High included in this study show some signs of post-crystallisation alteration. Late-stage magmatic alteration 
is most likely responsible for the widespread sericitisation of plagioclase and the chloritisation of biotite. It is likely that basement rocks, now covered by Permian sediments, were exposed at the time and acted as source area for the Rotliegendes conglomerates which can be found in half-grabens on the high. However, it cannot be concluded whether the observed secondary mineral phases were formed just by subaerial weathering or as a result of diagenetic transformation. From Late Triassic time, the basement was subaerially exposed and weathering took place. Well-developed weathering profiles are observed in both 16/1-15 and $16 / 3-4$, represented both by the clay mineral association and the upwards-increasing alteration. Furthermore, it can be concluded that the two wells display differences in the amounts of clays and clay minerals, indicating that they were formed under different climatic conditions or at different topographic levels. The Avaldsnes hwas transgressed in the Late Jurassic, whereas the Haugaland high remained dry land until the Early Cretaceous and represents the final stage of the exposure of the high. The petroleum geological significance of the fractured and weathered basement is believed to have its largest potential as migration paths for hydrocarbons, but can also contribute to the reservoir locally where deepweathered rocks are preserved. Saprolites developed from acidic basement rocks are believed to have better reservoir potential than metamorphic (more resistant mineral composition) and gabbroic rocks (thinner saprolite horizon).

Acknowledgements. This study has been funded by Lundin Norway AS. Access to the cores presented in this study has kindly been granted by Lundin Norway AS and the Norwegian Petroleum Directorate (NPD). A special thanks to Dag Bering and Robert W. Williams at NPD. Thanks to Maarten Aerts, Berit Løken Berg and Salahalldin Akhavan at the University of Oslo, and Lars Kirksæther at Petro-Sec for helping out with sample preparation and analyses. Thanks to Christine Haas for reviewing the manuscript and to Adrian Read for correcting the English. Valuable comments and improvements that have been provided by Fridtjof Riis and one anonymous reviewer are highly appreciated.

\section{Reference list}

Abbink, O., Targarona, J., Brinkhuis, H. \& Visscher, H. 2001: Late Jurassic to earliest Cretaceous palaeoclimatic evolution of the southern North Sea. Global and Planetary Change 30, 231-256. doi: http:// dx.doi.org/10.1016/S0921-8181(01)00101-1.

Acworth, R.I. 1987: The development of crystalline basement aquifers in a tropical environment. Quarterly journal of engineering geology and hydrogeology 20, 265-272. doi: 10.1144/gsl.qjeg.1987.020.04.02.

Ahlberg, A., Olsson, I. \& Šimkevičius, P. 2003: Triassic-Jurassic weathering and clay mineral dispersal in basement areas and sedimentary basins of southern Sweden. Sedimentary Geology 161, 15-29. doi: 10.1016/s0037-0738(02)00381-0.

Bergslien, D. 2002: Balder and Jotun - two sides of the same coin? A comparison of two Tertiary oil fields in the Norwegian North Sea. Petroleum Geoscience 8, 349-363. doi: 10.1144/petgeo.8.4.349.
Besly, B.M. 1998: Carboniferous. In Glennie, K.W. (ed.): Petroleum Geology of the North Sea: Basic Concepts and Recent Advances, Fourth Edition, Blackwell Science,London, pp. 104-136. doi: http:// dx.doi.org/10.1002/9781444313413.

Bjørkum, P.A. \& Gjelsvik, N. 1988: An isochemical model for formation of authigenic kaolinite, k-feldspar and illite in sediments. Journal of Sedimentary Petrology 58, 506-511.

Brekke, H., Sjulstad, H.I., Magnus, C. \& Williams, R.W. 2001: Sedimentary environments offshore Norway - an overview. In Ole, J.M. \& Tom, D. (eds.): Sedimentary Environments Offshore Norway - Palaeozoic to Recent, Proceedings of the Norwegian Petroleum Directorate, Norwegian Petroleum Society Special Publication 10, pp. 7-37. doi: 10.1016/S0928-8937(01)80006-0.

Bruce, D.R.S. \& Stemmerik, L. 2003: Carboniferous. In Evans, D., Graham, C., Armour, A. \& Bathurst, P. (eds.): The Millennium Atlas: Petroleum geology of the central and northern North Sea, The Geological Society of London, London, pp. 83-89.

Bruhn, R., Parry, W., Yonkee, W. \& Thompson, T. 1994: Fracturing and hydrothermal alteration in normal fault zones. Pure and Applied Geophysics 142, 609-644. doi: 10.1007/BF00876057.

Buol, S.W. \& Weed, S.B. 1991: Saprolite-soil transformations in the Piedmont and Mountains of North Carolina. Geoderma, 51, 15-28.

Charnock, M., Kristiansen, I., Ryseth, A. \& Fenton, J. 2001: Sequence stratigraphy of the Lower Jurassic Dunlin Group, northern North Sea. In Martinsen, O.J. \& Dreyer, T. (eds.): Sedimentary Environments Offshore Norway - Palaeozoic to Recent, Proceedings of the Norwegian Petroleum Directorate, Norwegian Petroleum Society Special Publication 10, pp. 145-174. doi: 10.1016/S0928-8937(01)80012-6.

Chester, F.M., Evans, J.P. \& Biegel, R.L. 1993: Internal structure and weakening mechanisms of the San Andreas fault. Journal of Geophysical Research: Solid Earth 98, 771-786. doi: 10.1016/01489062(93)92238-L.

Clauer, N., Frape, S.K. \& Fritz, B. 1989: Calcite veins of the Stripa granite (Sweden) as records of the origin of the groundwaters and their interactions with the granitic body. Geochimica et Cosmochimica Acta, 53, 1777-1781. doi: http://dx.doi.org/10.1016/00167037(89)90298-6.

Clemmensen, L., Steel, R. \& Jacobsen, V. 1980: Some aspects of Triassic sedimentation and basin development: east Greenland, north Scotland and North Sea. In Norsk Petroleumsforening, The Sedimentation of North Sea Reservoir Rocks, 11-14 May, Geilo, Norway, pp. 1-21.

Coward, M.P., Dewey, J.F., Hempton, M., Holroyd, L. \& Mange, M.A. 2003: Tectonic evolution. In Evans, D., Graham, C., Armour, A. \& Bathurst, P. (eds.): The Millennium Atlas: Petroleum geology of the central and northern North Sea, The Geological Society of London, London, pp. 17-33.

Davies, R.J., O’Donnell, D., Bentham, P.N., Gibson, J.P.C., Curry, M.R., Dunay, R.E. \& Maynard, J.R. 1999: The origin and genesis of major Jurassic unconformities within the triple junction area of the North Sea, UK. Geological Society of London, Petroleum Geology Conference Series 5, 117-131. doi: 10.1144/0050117.

Downie, R. 1998: Devonian. In Glennie, K.W. (ed.): Petroleum Geology of the North Sea: Basic Concepts and Recent Advances, Fourth Edition, Blackwell Science, London, pp. 85-103. doi: http://dx.doi. org/10.1002/9781444313413

Dypvik, H. 1981: Drilling mud contamination of samples in X-ray diffraction and atomic absorption analyses. Geologic Notes. American Association of Petroleum Geologists Bulletin 65, 744-748. doi: http:// dx.doi.org/10.1306/2F9199C2-16CE-11D7-8645000102C1865D.

Eggleton, R.A. \& Banfield, J.F. 1985: The alteration of granitic biotite to chlorite. American Mineralogist 70, 902-910.

Farag, S.M., Le, H.V., Mas, C., Maizeret, P.-D., Li, B. \& Dang, T. 2009: Advances in granitic basement reservoir evaluation. Paper presented at the Asia Pacific Oil and Gas Conference \& Exhibition, 4-6 August, Jakarta, Indonesia, pp. 1-15 
Fisher, M.J. \& Mudge, D.C. 1998: Triassic. In Glennie, K.W. (ed.): Petroleum Geology of the North Sea: Basic Concepts and Recent Advances, Fourth Edition, Blackwell Science, London. pp. 212-44. doi: http:// dx.doi.org/10.1002/9781444313413.

Fossen, H., Dallmann, W. \& Andersen, T.B. 2008: The mountain chain rebounds and founders. The Caledonides are worn down: 405-359 million years. In Ramberg, I.B., Bryhni, I., Nøttvedt, A. \& Rangnes, K. (eds.): The making of a Land. Geology of Norway, Norsk Geologisk Forening, pp. 232-259.

Fredin, O., Zwingmann, H., Knies, J., Sørlie, R., Grandal, E.M., Lie, J.E., Müller, A. \& Vogt, C. 2014: Saprolites on- and offshore Norway: New constraints on formation processes and age. Programme with Abstracts, $31^{\text {st }}$ Nordic Geological Winter Meeting, 8-10 January, Lund, Sweden, p. 132.

Frost, R., Fitch, F. \& Miller, J. 1981: The age and nature of the crystalline basement of the North Sea Basin. In Illing, L.V. \& Hobson, G.D. (eds.): Petroleum Geology of the Continental Shelf of North-West Europe, Heyden and Son on behalf of The Institute of Petroleum, London, pp. 43-57.

Færseth, R., Gabrielsen, R., \& Hurich, C. 1995: Influence of basement in structuring of the North Sea basin, offshore southwest Norway. Norwegian Journal of Geology, 75, 105-119.

Gabrielsen, R.H., Faleide, J.I., Pascal, C., Braathen, A., Nystuen, J.P., Etzelmuller, B. \& O’Donnell, S. 2010: Latest Caledonian to Present tectonomorphological development of southern Norway. Marine and Petroleum Geology 27, 709-723. doi: 10.1016/j.marpetgeo.2009.06.004.

Galán, E. 2006: Genesis of clay minerals. In Bergaya, F., Theng, B.K.G. \& Lagaly, G. (eds.): Handbook of Clay Science, Developments in Clay Science 1, Elsevier, Amsterdam, pp. 1129-1162.

Galán, E. \& Ferrell, R.E. 2013: Genesis of Clay Minerals. In Bergaya, F. \& Lagaly, G. (eds.): Handbook of Clay Science, Developments in Clay Science 5, Elsevier, Amsterdam, pp. 83-126.

Gee, D.G., Fossen, H., Henriksen, N. \& Higgins, A. 2008: From the early Paleozoic platforms of Baltica and Laurentia to the Caledonide orogen of Scandinavia and Greenland. Episodes 31, 44-51.

Glennie, K.W. 1995: Permian and Triassic rifting in northwest Europe. Geological Society of London Special Publications 91, pp. 1-5. doi: 10.1144/GSL.SP.1995.091.01.01.

Glennie, K.W. \& Underhill, J.R. 1998: Origin, development and evolution of structural styles. In Glennie, K.W. (ed.): Petroleum Geology of the North Sea: Basic Concepts and Recent Advances, Fourth Edition, Blackwell Science, London, pp. 42-84. doi: http://dx.doi. org/10.1002/9781444313413.

Goldich, S.S. 1938: A Study in Rock-Weathering. The Journal of Geology, 46, 17-58. doi: 10.2307/30079586.

Gregersen, U., Michelsen, O. \& Sørensen J.C. 1997: Stratigraphy and facies distribution of the Utsira Formation and the Pliocene sequences in the northern North Sea. Marine and Petroleum Geology 14, 893-914.

Gutmanis, J. 2009: Basement reservoirs - A review of their geological and production characteristics. Paper presented at the International Petroleum Technology Conference, 7-9 December, Doha, Qatar, pp. 1-7.

Hallam, A., Crame, J.A., Mancenido, M.O., Francis, J. \& Parrish, J.T. 1993: Jurassic climates as inferred from the sedimentary and fossil record [and Discussion]. Philosophical Transactions of the Royal Society of London. Series B: Biological Sciences 341, 287-296. doi: 10.1098/rstb.1993.0114.

Hamar, G., Jakobsson, K., Ormaasen, D. \& Skarpnes, O. 1980: Tectonic development of the North Sea north of the Central Highs. In Norsk Petroleumsforening, The Sedimentation of the North Sea Reservoir Rocks, 11-14 May, Geilo, Norway, pp. 1-11.

Hillier, S. 2000: Accurate quantitative analysis of clay and other minerals in sandstones by XRD: comparison of a Rietveld and a reference intensity ratio (RIR) method and the importance of sample preparation. Clay Minerals 35, 291-291. doi: http://dx.doi. org/10.1180/000985500546666.
Husmo, T., Hamar, G.P., Høiland, O., Johannessen, E.O., Rømuld, A., Spencer, A.M. \& Titterton, R. 2002: Lower and Middle Jurassic. In Evans, D., Graham, C., Armour, A. \& Bathurst, P. (eds.): The Millennium Atlas: Petroleum geology of the central and northern North Sea, The Geological Society of London, London, pp. 129-155.

International Society of Rock Mechanics 1978: Methods for the quantitative description of rock masses and discontinuities. International Journal of Rock Mechanics, Mining. Sciences and Geomechanics 15, 319-368.

Jackson, C.A.L., Kane, K.E., \& Larsen, E. 2010: Structural evolution of minibasins on the Utsira High, northern North Sea; implications for Jurassic sediment dispersal and reservoir distribution. Petroleum Geoscience 16, 105-120. doi: 10.1144/1354-079309-011.

Ksienzyk, A.K., Jacobs, J., Fossen, H., Dunkl, I. \& Košler, J. 2013: The basement of the Utsira High: U/Pb, (U/Th)/He and fission track thermochronology. Abstracts and Proceedings of the Geological Society of Norway, Vinterkonferansen 2013, 8-10 January, Oslo, Norway, p. 75.

Landes, K.K, Amoruso, J.J., Charlesworth, L.J., Heany, F. \& Lesperance, P.J. 1960: Petroleum resources in basement rocks. American Association of Petroleum Geologists Bulletin, 44, 1682-1691.

Laursen, I., Fugelli, E. \& Lervik, K.S. 1995: Sequence stratigraphic framework of the Paleocene and Eocene successions, block 16/1, Norwegian North Sea. In Steel, R.J. \& Mathieu, C. (eds.): Sequence Stratigraphy on the Northwest European Margin, Norwegian Petroleum Society Special Publication 5, pp. 471-481. doi: 10.1016/ S0928-8937(06)80082-2.

Le Maitre, R.W. \& Bateman, P. 1989: A classification of igneous rocks and glossary of terms: recommendations of the International Union of Geological Sciences Subcommission on the Systematics of Igneous Rocks. Blackwell, Oxford, 193 pp.

Lervik, K.S. 2006: Triassic lithostratigraphy of the Northern North Sea Basin. Norwegian Journal of Geology 86, 93-116.

Lidmar-Bergström, K. 1982: Pre-Quaternary geomorphological evolution in southern Fennoscandia. Sveriges Geologiska Undersøkning Serie C 785, 202 pp.

Lidmar-Bergström, K. 1993: Denudation surfaces and tectonics in the southernmost part of the Baltic Shield. Precambrian Research 64, 337-345. doi: 10.1016/0301-9268(93)90086-h.

Lidmar-Bergström, K. 1995: Relief and saprolites through time on the Baltic Shield. Geomorphology 12, 45-61. doi: 10.1016/0169$555 x(94) 00076-4$.

Lidmar-Bergström, K. 1996: Long term morphotectonic evolution in Sweden. Geomorphology 16, 33-59.

doi: 10.1016/0169-555x(95)00083-h.

Lidmar-Bergström, K. 1999: Uplift histories revealed by landforms of the Scandinavian domes. Geological Society of London Special Publications 162, 85-91. doi: 10.1144/gsl.sp.1999.162.01.07.

Lidmar-Bergström, K., Olsson, S. \& Roaldset, E. 2009: Relief features and palaeoweathering remnants in formerly glaciated Scandinavian basement areas. In Thiry, M. \& Simon-Coinçoin, R. (eds.): Palaeoweathering, Palaeosurfaces and Related Continental Deposits, Blackwell, Oxford, pp. 275-301.

Lundmark, A.M., Sæther, T. \& Sørlie, R. 2013: Ordovician to Silurian magmatism on the Utsira High, North Sea: implications for correlations between the onshore and offshore Caledonides. Geological Society of London Special Publications 390, 513-523. doi: 10.1144/SP390.21.

Lundmark, A.M., Bue, E.P., Gabrielsen, R.H., Flaat, K., Strand, T. \& Ohm, S.E. 2014: Provenance of late Palaeozoic terrestrial sediments on the northern flank of the Mid North Sea High: detrital zircon geochronology and rutile geochemical constraints, Geological Society of London Special Publications 386, 243-259. doi: 10.1144/SP386.4.

Mantovani, M. \& Becerro, A.I. 2010: Illitization of kaolinite: The effect of pressure on the reaction rate. Clays and Clay Minerals 58, 766771. doi: $10.1346 / \mathrm{ccmn} .2010 .0580604$. 
Marshall, J.E.A. \& Hewett, A.J. 2003: Devonian. In Evans, D., Graham, C., Armour, A. \& Bathurst, P. (eds.): The Millennium Atlas: Petroleum geology of the central and northern North Sea. The Geological Society of London, London, pp. 65-81.

Martin, C.A., Stewart, S.A., \& Doubleday, P.A. 2002: Upper Carboniferous and Lower Permian tectonostratigraphy on the southern margin of the Central North Sea. Journal of the Geological Society of London 159, 731-749. doi: 110.1144/0016-764900-174.

McKie, T. \& Williams, B. 2009: Triassic palaeogeography and fluvial dispersal across the northwest European Basins. Geological Journal 44,711-741. doi: 10.1002/gj.1201.

Migoń, P. \& Lidmar-Bergström, K. 2001: Weathering mantles and their significance for geomorphological evolution of central and northern Europe since the Mesozoic. Earth - Science Reviews 56, 285324. doi: http://dx.doi.org/10.1016/S0012-8252(01)00068-X.

Moore, D.M. \& Reynolds, R.C. 1997: X-ray Diffraction and the Identification and Analysis of Clay Minerals. Oxford University Press, New York, 378 pp.

Nahon, D.B. 1991: Self-organization in chemical lateritic weathering. Geoderma 51, 5-13.

Nelson, R.A. 2001: Geologic analysis of naturally fractured reservoirs. Gulf Professional Publishing, Boston, 332 pp.

Nesbitt, H.W. \& Young, G.M. 1989: Formation and Diagenesis of Weathering Profiles. The Journal of Geology 97, 129-147.

NORLEX Project 2012: http://www.nhm2.uio.no/norlex/StandardLithostratigraphicWallchartOffshoreNorway.pdf

Nøttvedt, A., Gabrielsen, R. \& Steel, R. 1995: Tectonostratigraphy and sedimentary architecture of rift basins, with reference to the northern North Sea. Marine and Petroleum Geology 12, 881-901. doi: 10.1016/0264-8172(95)98853-W.

Nøttvedt, A., Johannessen, E.P. \& Surlyk, F. 2008: The Mesozoic of western Scandinavia and East Greenland. Episodes 31, 59-65.

Odinsen, T., Reemst, P., Van Der Beek, P., Faleide, J.I. \& Gabrielsen, R.H 2000: Permo-Triassic and Jurassic extension in the northern North Sea: results from tectonostratigraphic forward modelling. Geological Society of London Special Publications 167, 83-103.

Olesen, O., Dehls, J.F., Ebbing, J., Henriksen, H., Kihle, O. \& Lundin, E. 2006: Aeromagnetic mapping of deep-weathered fracture zones in the Oslo Region - A new tool for improved planning of tunnels. Norwegian Journal of Geology 87, 253-267.

Olesen, O., Pascal Kierulf, H., Brönner, M., Dalsegg, E., Fredin, O. \& Solbakk, T. 2013: Deep weathering, neotectonics and strandflat formation in Nordland, northern Norway. Norwegian Journal of Geo$\log y$ 93, 189-213.

Pacheco, F.A. \& Alencoão, A.M. 2006: Role of fractures in weathering of solid rocks: narrowing the gap between laboratory and field weathering rates. Journal of Hydrology 316, 248-265. doi: 10.1016/j. jhydrol.2005.05.003.

Pharaoh, T.C. 1999: Palaeozoic terranes and their lithospheric boundaries within the Trans-European Suture Zone (TESZ): a review. Tectonophysics 314, 17-41.

Pharaoh, T.C., Dusar, M., Geluk, M.C., Kockel, F., Krawczyk, C.M., Krzywiec, P., Scheck, Wenderoth, M., Thybo, H., Vejbaek, O.V. \& van Wees, J.D. 2010: Tectonic evolution of Southern Permian Basin. In Doornenbal, H. \& Stevenson, A. (eds.): Petroleum Geology Atlas of the Southern Permian Basin Area, European Association of Geoscientists \& Engineers Publications B.V., Houten, The Netherlands, pp. 25-57.

Preto, N., Kustatscher, E. \& Wignall, P.B. 2010: Triassic climates - State of the art and perspectives. Palaeogeography, Palaeoclimatology, Palaeoecology 290, 1-10. doi: 10.1016/j.palaeo.2010.03.015.

Que, M. \& Allen, A.R. 1996. Sericitization of plagioclase in the Rosses Granite Complex, Co. Donegal, Ireland. Mineralogical Magazine, 60, 927-936.

Rey, P., Burg, J.-P. \& Casey, M. 1997: The Scandinavian Caledonides and their relationship to the Variscan belt. In Burg, J.P. \& Ford, M. (eds): Orogeny Through Time, Geological Society of London Special Publications 121, pp. 179-200. doi: 10.1144/GSL.SP.1997.121.01.08.
Rietveld, H.M. 1969: A profile refinement method for nuclear and magnetic structures. Journal of applied crystallography 2, 65-71. doi: $10.1107 /$ S0021889869006558.

Riis, F. 1996: Quantification of Cenozoic vertical movements of Scandinavia by correlation of morphological surfaces with offshore data. Global and Planetary Change 12,331-357.

Roaldset, E., Pettersen, E., Longva, O. \& Mangerud, J. 1982: Remnants of preglacial weathering in western Norway. Norwegian Journal of Geology 62, 169-178.

Roaldset, E., Riis, F. \& Johnsen, S.O. 1993: Weathered basement rocks below Mesozoic sediments, Norwegian North Sea. In Ford, D., McCann, B. \& Vajocczki, S. (eds.): Programme with Abstracts, Third International Geomorphology Conference, 23-28 August, Hamilton, Ontario, Canada, p. 229.

Sequeira Braga, M.A., Lopes Nunes, J.E., Paquet, H. \& Millot, G. 1990: Climatic zonality of coarse granitic saprolites ("Arenes") in Atlantic Europe from Scandinavia to Portugal. Paper presented at the 9th International Clay Conference, 28 August - 2 September, Strasbourg, France, pp. 99-108.

Seranne, M. \& Seguret, M. 1987: The Devonian basins of western Norway: tectonics and kinematics of an extending crust. In Coward, M.P., Dewey, J.F. \& Hancock, P.L. (eds.): Continental Extensional Tectonics, Geological Society of London Special Publications 28, pp. 537-548. doi: 10.1144/gsl.sp.1987.028.01.35.

Slagstad, T., Davidsen, B. \& Daly, J.S. 2011: Age and composition of crystalline basement rocks on the Norwegian continental margin: offshore extension and continuity of the Caledonian-Appalachian orogenic belt. Journal of the Geological Society of London 168, 11671185. doi: 10.1144/0016-76492010-136.

Soper, N., England, R., Snyder, D., \& Ryan, P. 1992: The Iapetus suture zone in England, Scotland and eastern Ireland: a reconciliation of geological and deep seismic data. Journal of the Geological Society of London 149, 697-700.

Speer, J.A. 1984: Micas in igneous rocks. In Bailey, S.W. (ed.): Micas, Reviews in Mineralogy 13, Mineralogical Society of America, Washington D.C., pp. 299-356.

Steel, R. \& Ryseth, A. 1990: The Triassic-Early Jurassic succession in the northern North Sea: megasequence stratigraphy and intra-Triassic tectonics. Geological Society of London Special Publications 55, $139-168$.

Sørensen, R. 1988: In situ rock weathering in Vestfold, southeastern Norway. Geografiska Annaler. Series A. Physical Geography 70, 299308.

Sørensen, S. \& Martinsen, B.B. 1987: A paleogeographic reconstruction of the Rotliegends deposits in the Northeastern Permian Basin. In Brooks, J. \& Glennie, K.W. (eds.): Petroleum Geology of North West Europe, Graham \& Trotman, London, pp. 497-508.

Sørlie, R., Hammer, E., Charnock, M., Amundsen, H. \& Riber, L. 2012: Integrated geological studies as a key to understanding the geology of the Johan Sverdrup discovery - with examples from the PL 501 area. Abstracts for the FORCE seminar "Jurassic and Lower Cretaceous Systems of the Utsira High", 19-20 June, Stavanger, Norway, p. 1.

Sørlie, R., Maast, T.E., Amundsen, H.E.F., Hammer, E., Charnock, M., Throndsen, I., Riber, L., Mearns, E.W., Dorn, A., Cummings, J. \& Fredin, O. 2014: Petrographic and Samarium-Neodymium isotope signatures of the Johan Sverdrup discovery, Norwegian North Sea. Presented at the "Brae Play" South Viking Graben, 22-27 April, Aberdeen, Scotland, pp. 29-32

Tardy, Y., Bocquier, G., Paquet, H. \& Millot, G. 1973: Formation of clay from granite and its distribution in relation to climate and topography. Geoderma 10, 271-284. doi: http://dx.doi. org/10.1016/0016-7061(73)90002-5.

Taylor, J.C.M. 1998: Upper Permian - Zechstein. In Glennie, K.W. (ed.): Petroleum Geology of the North Sea: Basic Concepts and Recent Advances, Fourth Edition, Blackwell Science, L, pp. 174-211. doi: http://dx.doi.org/10.1002/9781444313413. 
Vail, P.R., Mitchum Jr., R.M. \& Thompson III, S. 1977: Seismic Stratigraphy and Global Changes of Sea Level: Part 4. Global Cycles of Relative Changes of Sea Level. Section 2. Application of Seismic Reflection Configuration to Stratigraphic Interpretation. In Payton, C.E. (ed.): Seismic Stratigraphy - Applications to Hydrocarbon Exploration, American Association of Petroleum Geologists Special Publication M26, pp. 83-97.

Vollset, J. \& Doré, A.G. 1984: A revised Triassic and Jurassic lithostratigraphic nomenclature for the Norwegian North Sea. Norwegian Petroleum Directorate Bulletin 3, 53 pp.

Weaver, C.E. 1989: Clays, muds, and shales. Elsevier, Amsterdam, 819 pp.

Wilamowski, A. 2002: Chloritization and polytypism of biotite in the Łomnica granite, Karkonosze Massif, Sudetes, Poland: stable isotope evidence. Chemical Geology 182, 529-547. doi: 10.1016/S00092541(01)00344-8.

Woodcock, N. \& Mort, K. 2008: Classification of fault breccias and related fault rocks. Geological Magazine 145, 435-440. doi: 10.1017/ S0016756808004883.

Wright, E.P. 1992: The hydrogeology of crystalline basement aquifers in Africa. In Wright, E.P. \& Burgess, W.G. (eds.): Hydrogeology of Crystalline Basement Aquifers in Africa, Geological Society Special Publication 66, pp. 1-27. doi: 10.1144/GSL.SP.1992.066.01.01.

Ziegler, P.A. 1992: North Sea rift system. Tectonophysics 208, 55-75. doi: 10.1016/0040-1951(92)90336-5. 